\title{
Integrated geophysical and geochemical assessment of submarine groundwater discharge in coastal terrace of Tiruchendur, Southern India
}

\author{
J. Vinoth Kingston ${ }^{1,2}$ - A. Antony Ravindran ${ }^{1}$ - S. Richard Abishek ${ }^{1}$ - S. K. Aswin ${ }^{1}$ A. Antony Alosanai Promilton ${ }^{1}$
}

Received: 4 May 2020 / Accepted: 30 November 2021 / Published online: 14 December 2021

(C) The Author(s) 2021

\begin{abstract}
Submarine groundwater discharge (SGD) study is essential for groundwater in coastal terrace at Tiruchendur. The famous Murugan Temple is located in the area and around 25,000 people who visit this temple use the SGD well water at NaaliKinaru (a small open well) as holy water and drink it. The rock and soil type are sandy clay, silt, beach sand, calcarenite, kankar, gneissic rock and charnockite in base rock. Megascopic identification method was used to identify the porous and permeable rocks such as calcarenite, sandstone and kankar to support to increase SGD flux. Grain size study was used to identify the paleo-coastal estuarine environment with sediment deposits in the terrace. The square array electrical resistivity method was used to study the subsurface geology and aquifer depth. The $2 \mathrm{~d}$ ERT technique was used to identify the subsurface shallow perched aquifer of freshwater. The magnetotelluric survey method was used to scan the entire subsurface geological and tectonic uplift, coastal ridges, rock folded subsurface structural features of continental and oceanic tectonism. Darcy's law was used to calculate the SGD flux rate in the above study area.
\end{abstract}

Keywords SGD $\cdot$ Calcarenite $\cdot$ Grain size $\cdot$ Estuarine $\cdot$ Aquifer $\cdot$ Magnetotelluric

\section{Introduction}

The submarine groundwater discharge (SGD) study plays a major play role in the coastal aquifer and water resources management. Taniguchi and Makoto (2002), Robb (1990), Peng et al. (2008), Land and Paull (2000). Studying the SGD discharge with flux rate estimation is essential one for coastal zones monitoring of freshwater environment. Porubsky (2014), Burnett et al. (2006), The SGD discharge with flux rate estimation is essential one for monitoring of freshwater environment in coastal zones. Zhang et.al (2020), Duque et.al (2020). The huge volume of the freshwater is discharged into the oceans regularly due to heavy rain. Therefore, aquifer characteristic study is essential for

J. Vinoth Kingston

vinothkingston17@gmail.com

1 Present Address: Department of Geology, V.O. Chidambaram College, Thoothukudi 628008, Tamil Nadu, India

2 Manonmaniam Sundaranar University, Tirunelveli 627012, Tamil Nadu, India
SGD flux estimation. Prakash et al. (2018), Manivannan and Elango et al. (2019), Babu et al. (2009, 2021). An estimation of freshwater discharge using electrical resistivity methods of 2D ERT and magnetotelluric method. Ma and Zhang (2020), George et al. (2018), Jeyapaul et al. (2020), Ravindran et al. (2021). The main aim of discharge of freshwater is move through the sandstone formation. Geochemical studies were carried out by some researchers, Selvam et al. (2021a, b).

The study area is mostly covered with recent deposits of coastal alluvium, shell with marine environments of calcareous sandstone with shell material, Oolitic structure of lime, clay deposits in the study area. The terrace was formed due to the tectonic upliftment of coastal and continental movement. The Valli cave was formed by waves and is made up of lime calcareous kankar and calcarenite rocks. The terrace is completely made of calcareous materials. The "Naalli Kinaru" small open well is considered to be sacred and of divine origin. This is a small open well received the water from SGD discharge of water. A sub-stream of the Tamirabarani River once flowed toward the northern end of the Tiruchendur terrace.

The study area has semi-tropical climate condition. May to August is the hottest months. December to February is 
coolest months of the study area. The highest average temperature of around $35{ }^{\circ} \mathrm{C}$ is recorded in the month of June every year. The mean annual temperature is 28.3 . The mean annual precipitation is $675 \mathrm{~mm}$. Major rainfall is received during the northeast monsoon period between October and December. The maximum rainfall is usually received during November which is around $1131 \mathrm{~mm}$.

The coastal zone tapers downwards towards the sea. The costal sediments assume different forms along the coastal belt due to Neotectonic activities. Raised beaches and cliffed shoreline are observed in Tiruchendur. These beach ridges or terraces are covered by aeolian sands and are undulated with calcareous cementing medium. There are many silted up lagoons behind the beach ridges during the rainy season and the lagoons are filled with freshwater but become hypersaline during summer.

The important coastal features are bays, lagoons, estuaries, cliffs, dunes, backshore width, beach width, and wave cut features. The cliff section of rock calcarenite is made by high energy wave action and is cut into notches and caves at different levels in the terrace. In Tiruchendur, wave pressure generates high energy for erosion activity. The study focuses on the coast terrace of Tiruchendur. It is tectonically connected by the tributaries of the Tamirabarani channel. The study area Tiruchendur terrace is located in the middle part of the Gulf of Mannar coast.

\section{Material and methods}

The present study focuses on the discharge of freshwater into subsurface through hydraulic connection of sea bottom in the coastal terrace of Tiruchendur coast. The 2D electrical resistivity imaging (2D ERI), Electromagnetic, Geotechnical logging, Aquifer system, Topographical study, Tectonic settings of faulted movement through the satellite imagery wave were used for the aquifer characteristic study.

The 2D electrical resistivity imaging technique is used to find out the subsurface geological and hydrogeological aquifer thickness. The multicore cable with resistivity meter was used for the data collection in imaging study. The Werner configuration was used for this survey. The collected data were plotted in the Res2DINV software for pseudosection preparation with data interpretation.

In the present study, SGD flux estimation was studied with the help of 2D electrical resistivity, magnetotelluric, Bore hole drilling, grain size Granulometric study, Microscopic and Megascopic study of rocks. In thin section identification study was used for megascopic identification of rock with Quartz grains and association of Magnetite, Ilmenite, Zircon embedded to consolidate with cementing matrix of calcareous material.

\section{Megascopic Identification}

The petrological study of the rock revealed megascopically fine and oolitic texture of calcareous cemented sandstone, ferrous rich calcareous limestone, and oolitic texture with coarse and fine grained porous siliceous material cemented with lime material. Most of the parent rock is intergrowth and porous filling magnetite, illuminate mineral enriched. The paleo-river sediments and sandstone deposits are completely altered into metamorphic sheared grains from granitic rock with accessory minerals. The garnet, illuminate, embedded quartz and feldspar grains are seen in the entire rock. The Arkose rock contains feldspar and quartz type of mineral intergrowth in step like terrace (Barnard et al. 2013). The grains texture in the top to bottom level of the terrace is low to high sorting. The temperature variation and upliftment of shearing grain calcarenite are recorded in the stone. (Fig. 2).

The Valli Cave is made up of porous and permeable formation of calcarenite, sandstone and Kankar formation that is identified in the microscopic study.

\section{Microscopic identification}

In the microscopic identification of mineral and quartz with cementing matrix material, the followings were observed: the shape and size of minerals, grains with porous medium are also measured in the microscopic study.

\section{Electrical resistivity method (VES)}

Vertical Electrical Sounding (VES) method and SGD study have been carried out in various coasts of world. Burnett et al. (2006), Yadav (2019), Viso et al. (2010), Swarzenski and Izbicki et al. (2009), Henderson et al. (2010).

Five VES profiles were taken near the beach of Tiruchendur. The Azimuthal square array method was used to identify the deeper aquifer system and compare it with bore well litho log data. The aquameter is used for the data collection, the four copper electrodes, wire spool, with equal short interval of $1.75 \mathrm{~m}$ depth is followed for shallow aquifer identification. Azimuthal square array is a scientific method to cover more depth of penetration compare to Wenner configuration. Spacing (A) is equal to the depth of penetration. $p a=\frac{k \times v}{i}$; $\mathrm{Pa}=$ apparent resistivity, $\mathrm{K}=$ Geometric factor for the array, $\mathrm{V}=$ Potential differences in volt.

$\mathrm{I}=$ Current magnitude in amperes, $\mathrm{K}=$ Geometrical facto for square array formula.

$$
K=\frac{2 \pi A}{2-(2) 1 / 2}=\mathrm{k} \text { factor calculation formula of side length }
$$

of the square array method.

Square Array method electrode arrangement (Habberjam 1972; Habberjam and Watkins 1967; Antony Ravindran 2012). 


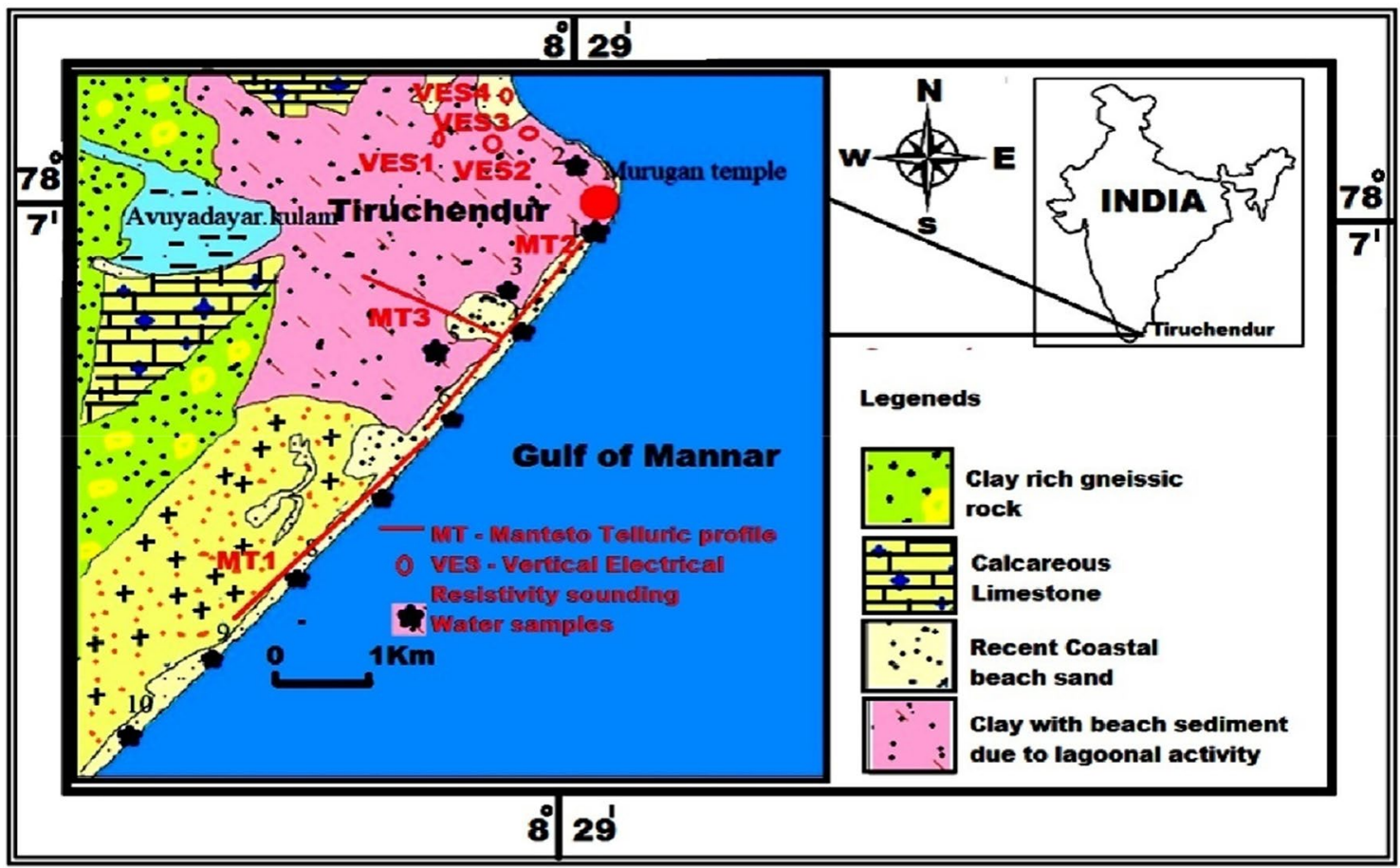

Fig. 1 Location map of the study area

Fig. 2 (a) Calcarenite rock (b) Beach rock exposure (c) Calcarenite in compact nature (d) Oolitic nature of calcarenite rock (e) Valli cave entrance (f) Valli cave below $15 \mathrm{~m}$ MSL
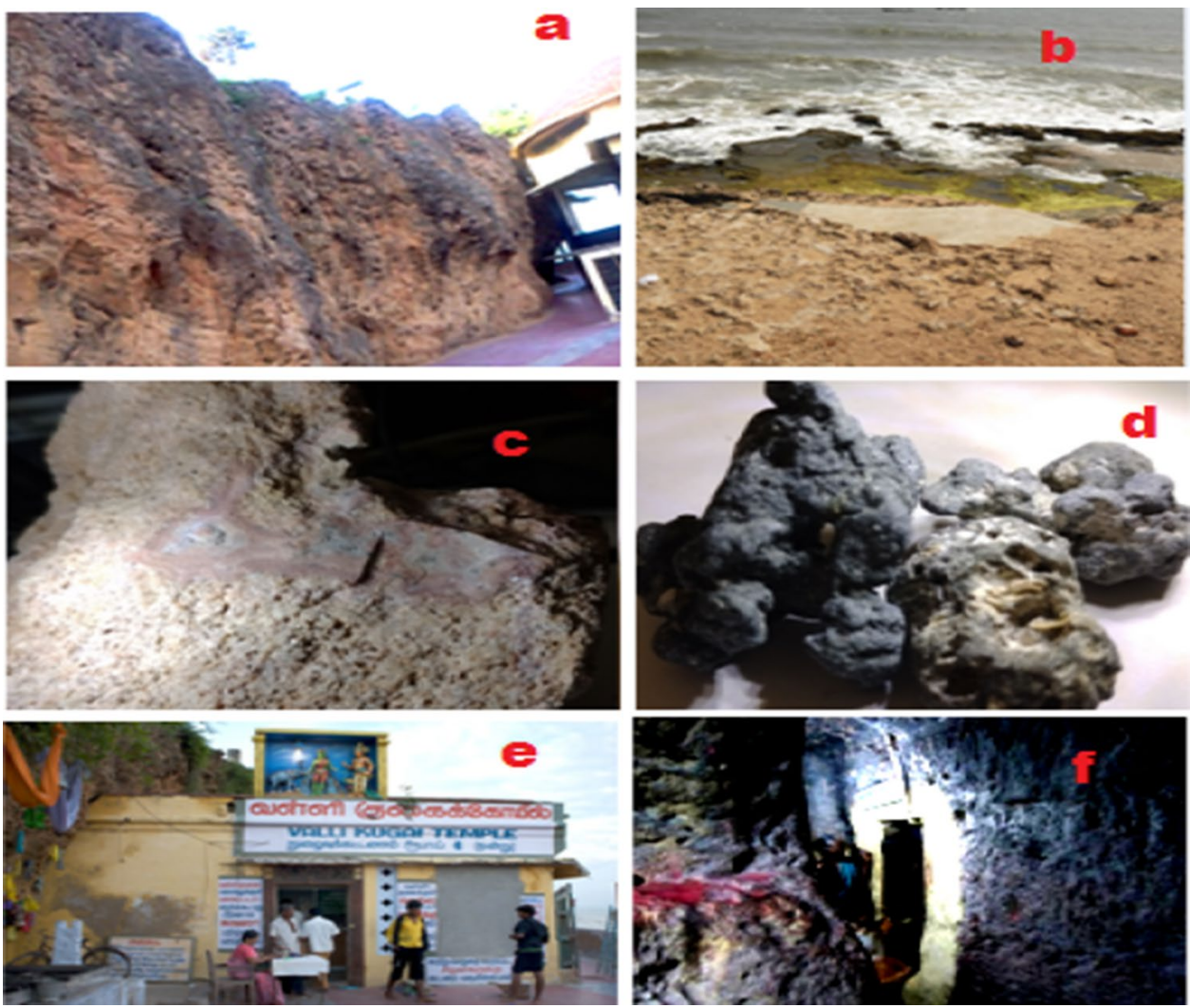

1

Springer 

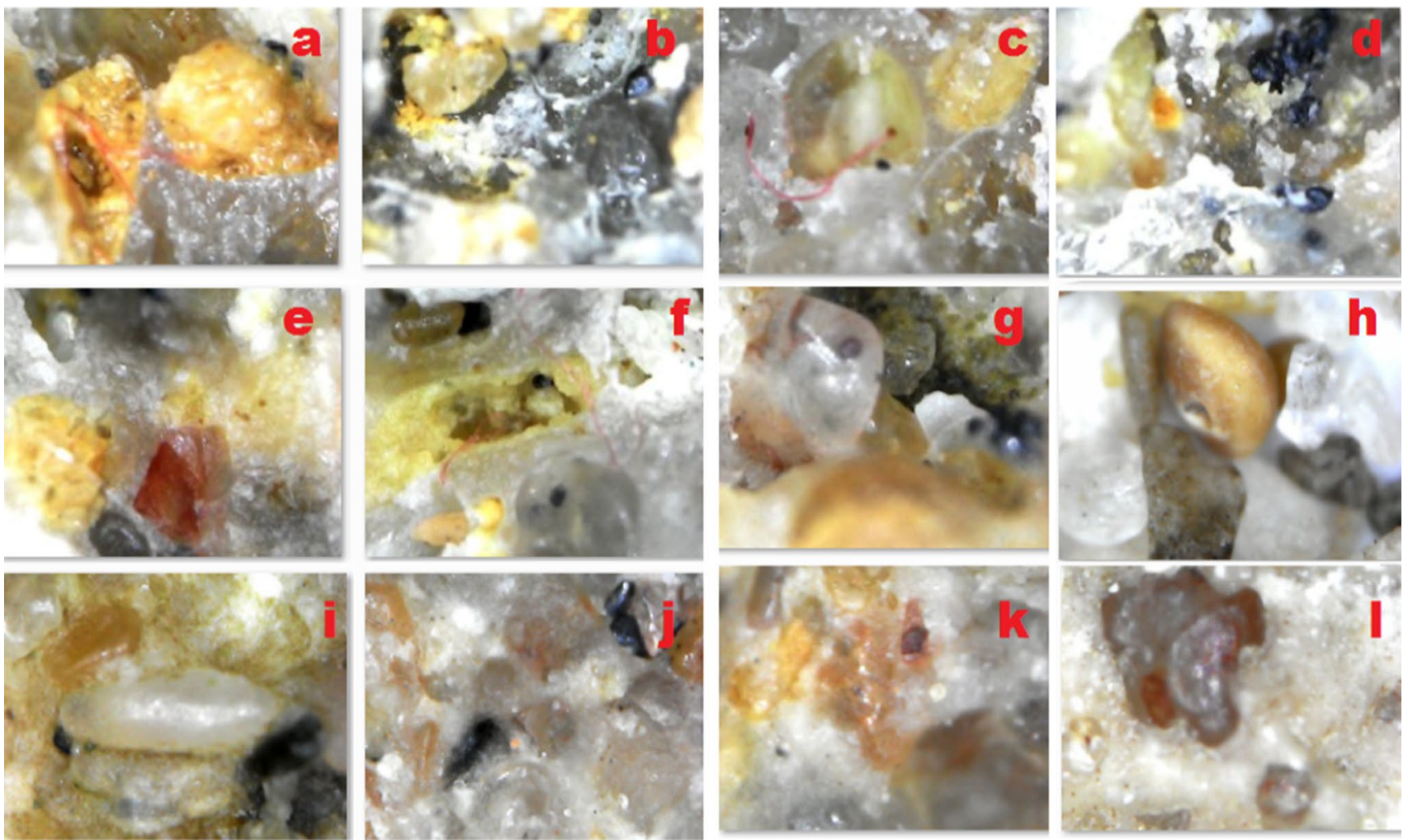

Fig. 3 ( a) Feldspar + quart matrix (b) Feldspar + biotite (c) Quartz cemented in feldspar (d) quartz + feldspar + biotite grains (e) rutile + feldspar $(\mathbf{f})$ pyroxene grain + quart $(\mathbf{g})$ quartz class embedded

by calcareous material (h) fossil in sandstone (i) angular shape quartz (j) quart matrix with other minerals (k) feldspar+quart matrix presents in quart (l) garnet grains with quartz

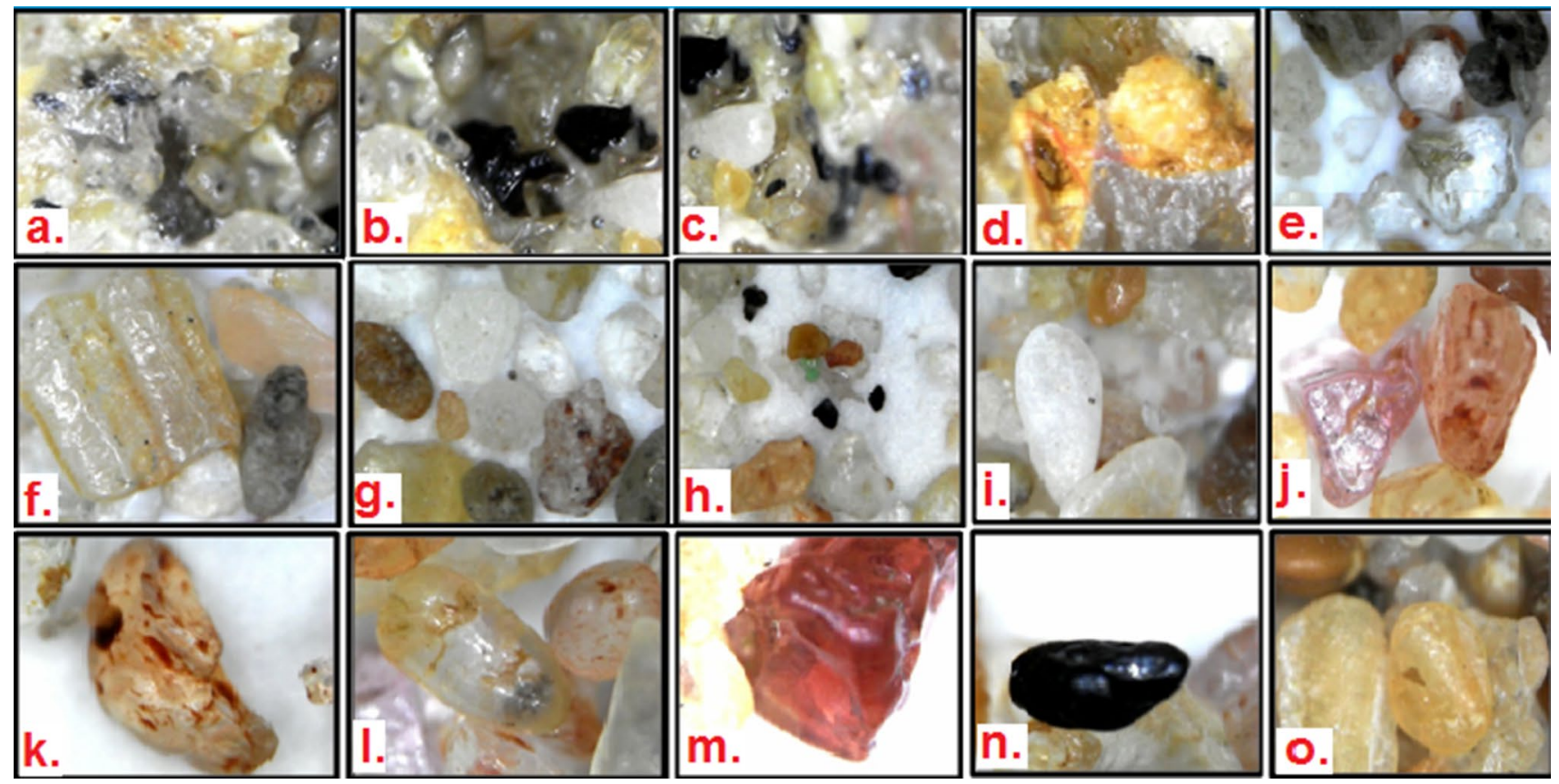

Fig. 4 (a) Quartz + feldspar (b) quartz + biotite (c) aggregate of quart + feldspar + biotite (d) feldspar alteration e) quartz cementing medium (f) shell material (g) garnet + apatite (h) milky quartz from quartzite area (i). wave sorted quartz grain (j) Rutile + apatite (k) quart grain weathered from quartzite ridge (l) well sorted quart grain from estuarine environment (m) Rutile (n) Zircon mineral (o) quartz 

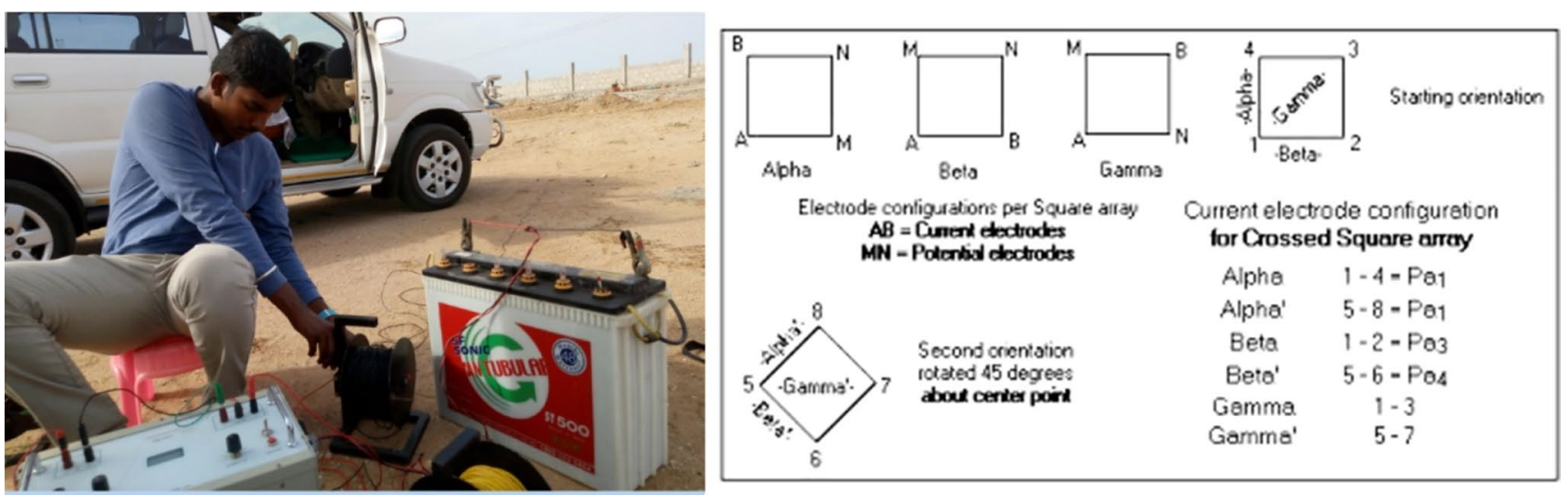

Fig. 5 Azimuthal square array data collection and electrode arrangements in Tiruchendur terrace

Fig. 6 Azimuthal square array electrical resistivity sounding profile 1

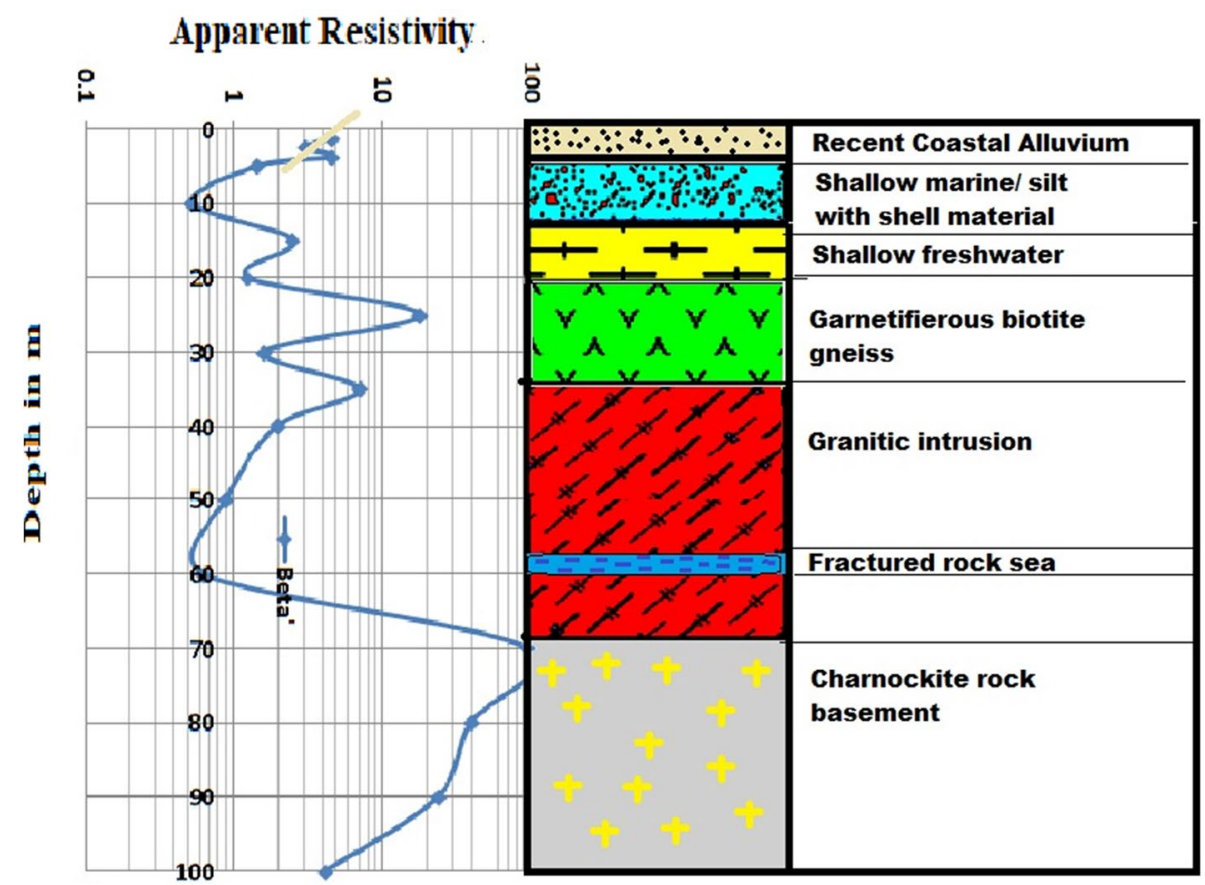

The shallow depth of resistivity is $10 \mathrm{ohms}$, and this is indicating the freshwater SGD flow in $10 \mathrm{~m}$ depth. The depth of $40,70 \mathrm{~m}$ is a freshwater resistivity range of $4 \mathrm{ohms}$. The seawater or saline interface is identified in the resistivity of 0.1-3 $\Omega$.

\section{D electrical resistivity imaging (ERI) study}

The 2D electrical resistivity imaging is a useful tool for SGD path study. The subsurface geology, freshwater and saline water studies were carried in the the 2D ERT equipment with multicore cable, 40 copper electrode, $12 \mathrm{~V}$ battery. The two ERT profiles were carried out from parallel to the coast of dunal area and near shoreline area covers a $300 \mathrm{~m}$ distance.

\section{Profile1}

Profile 1 covered a length of 300 m with Wenner-Schlumberger configuration. The subsurface geology showed the freshwater perched aquifer in the dunal area at depth of 6-8 m resistivity ranging from 4.00 to $5.00 \Omega . \mathrm{m}$ and this seen in the middle part of the area. The uplift of weahtered gnessic rock and its resisitivty is 5.00-700 $\Omega . \mathrm{m}$. The low resistiity is obtained from $2 \mathrm{~d}$ ERI pseudosection due to the seawater intrusion by dynamic wave action in the depth of $14 \mathrm{~m}$ (Fig. 10). 
Fig. 7 Azimuthal square array electrical resistivity sounding profile 2

Fig. 8 Azimuthal square array electrical resistivity sounding profile 3
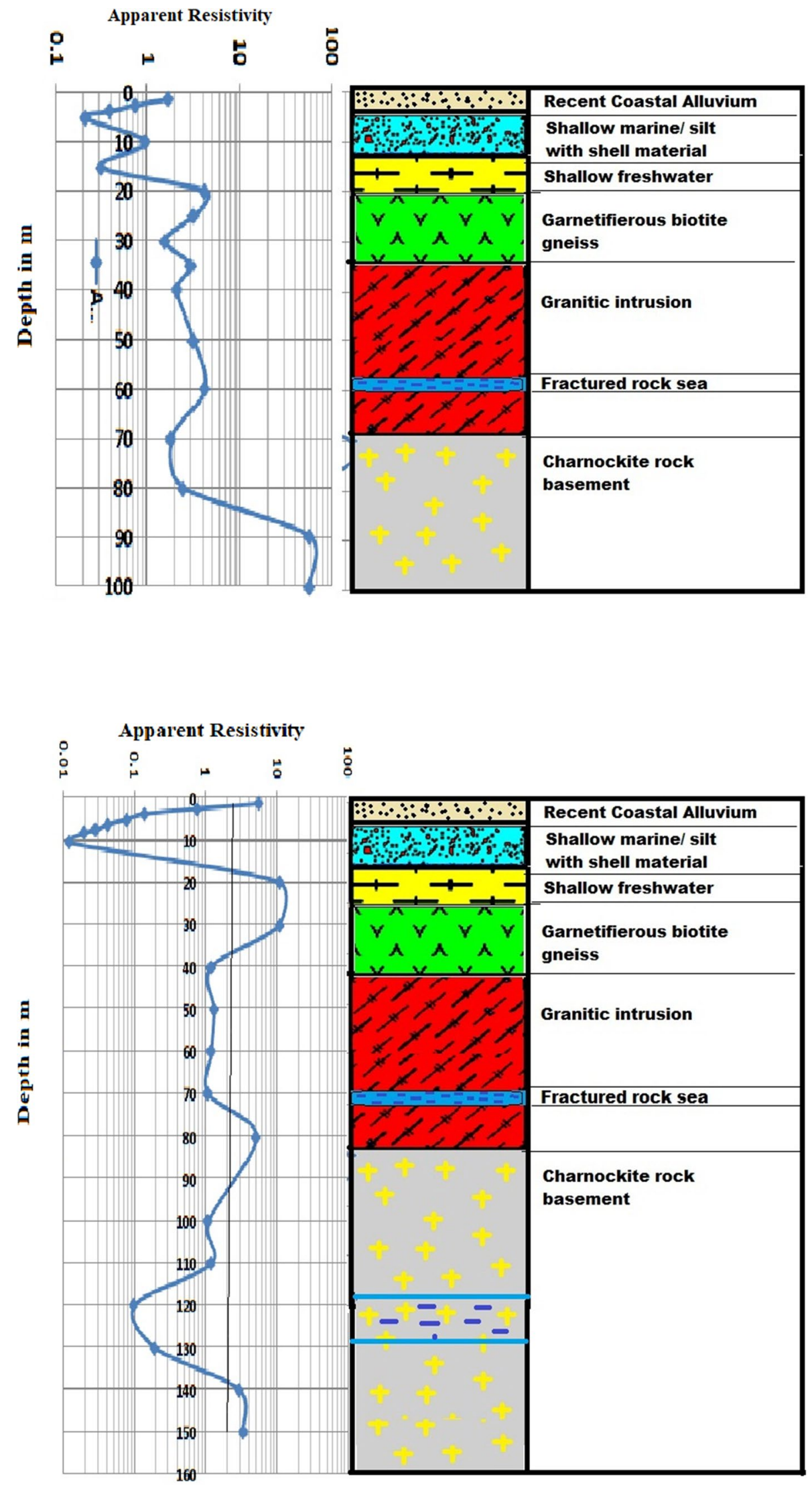
Fig. 9 Azimuthal square array electrical resistivity sounding profile 4

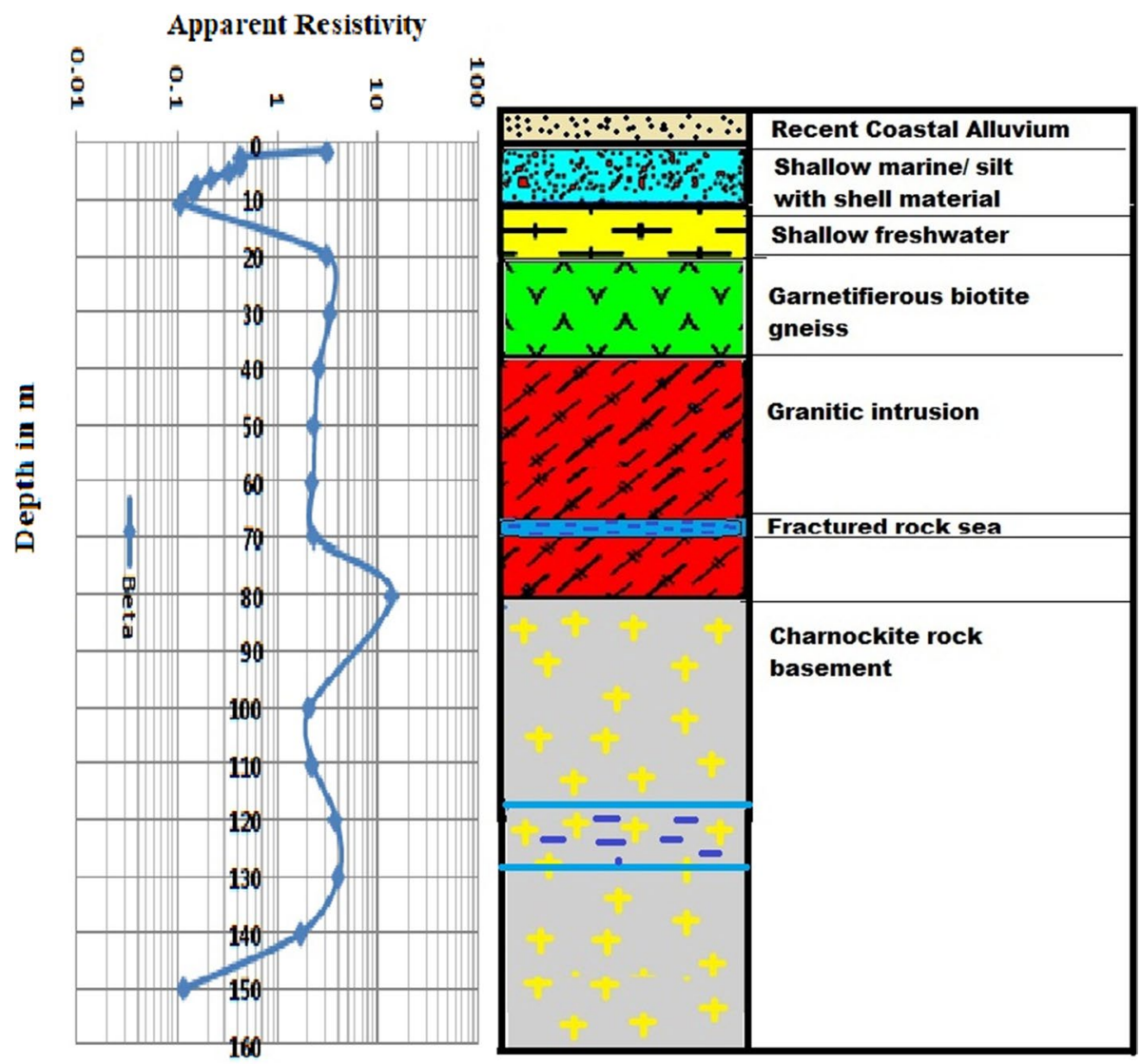

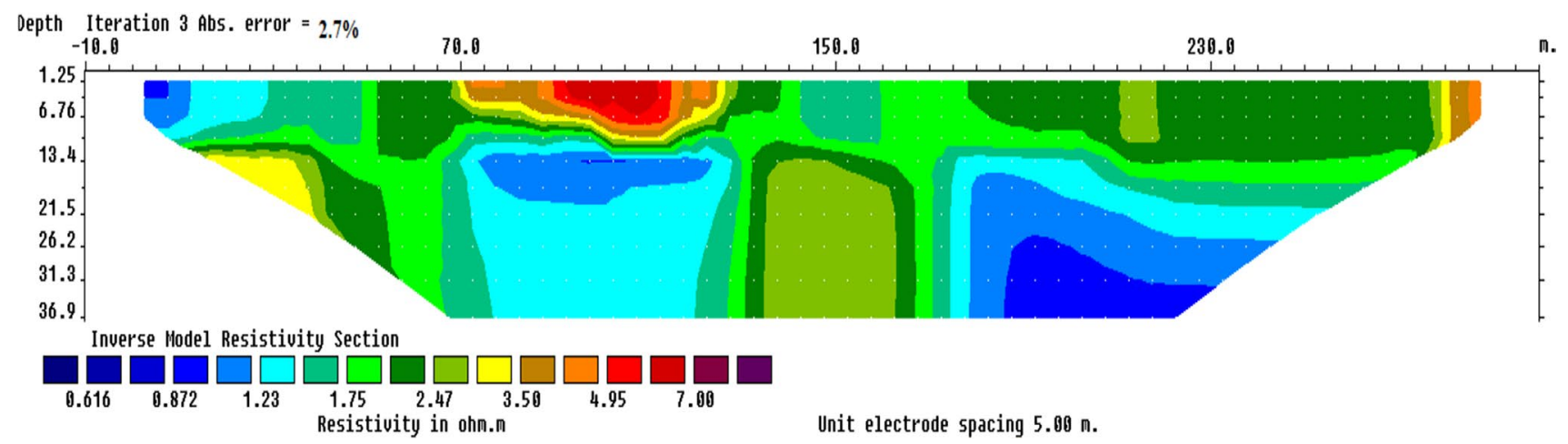

Fig. 10 Electrical resistivity imaging (ERI) Profile1

\section{Profile 2}

Profile 2 is covering $300 \mathrm{~m}$ distance of NE-SW direction of shoreline area. The upliftment of coastal granitic rock is intruded from the deeper level to top. The beach exposure is clearly seen in the 2D ERT pseudosection at an apparent resistivity of $2.38 \Omega . \mathrm{m}$. The low resistivity of seawater intrusion at shallow level is $0.863 \Omega . \mathrm{m}$. In the depth of $31.3 \mathrm{~m}$, an apparent resistivity is $4 \Omega . \mathrm{m}$ which indicates SGD. The freshwater is moving from highly elevated continental area to oceanic plate of coastal shore line area. (Fig. 11).

\section{Magnetotelluric method}

Magnetotelluric method is used to identify the subsurface geology, formation and freshwater discharge, Li and Jie (2017), Vozoff and Keeva (1991), Abdelzaher et al. (2012), 


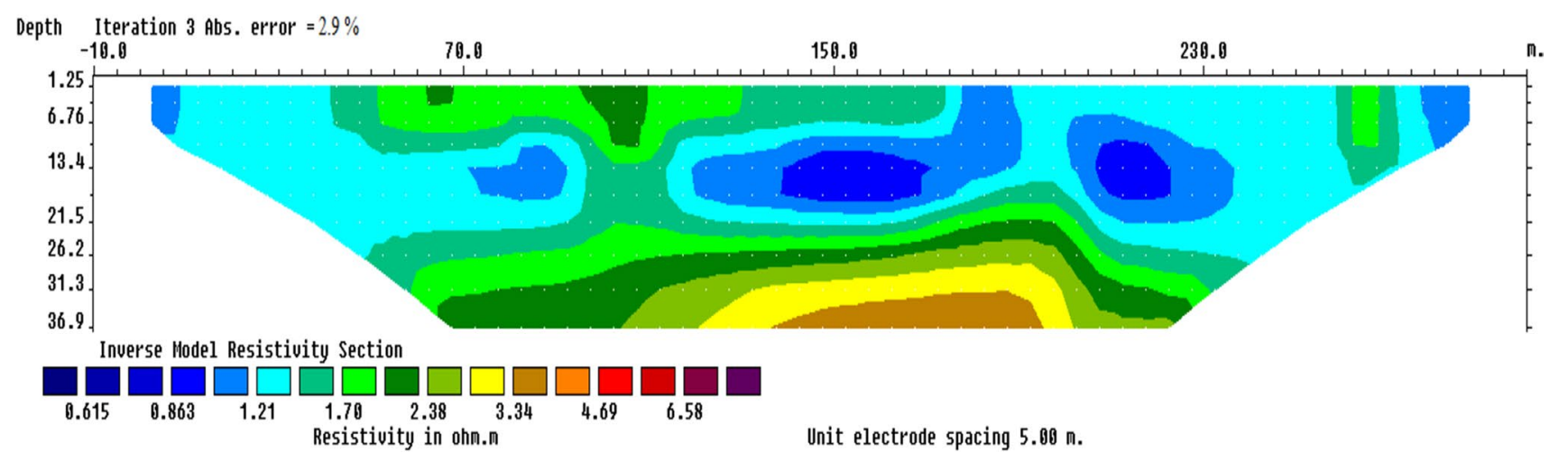

Fig. 11 Electrical resistivity imaging (ERI) Profile 2

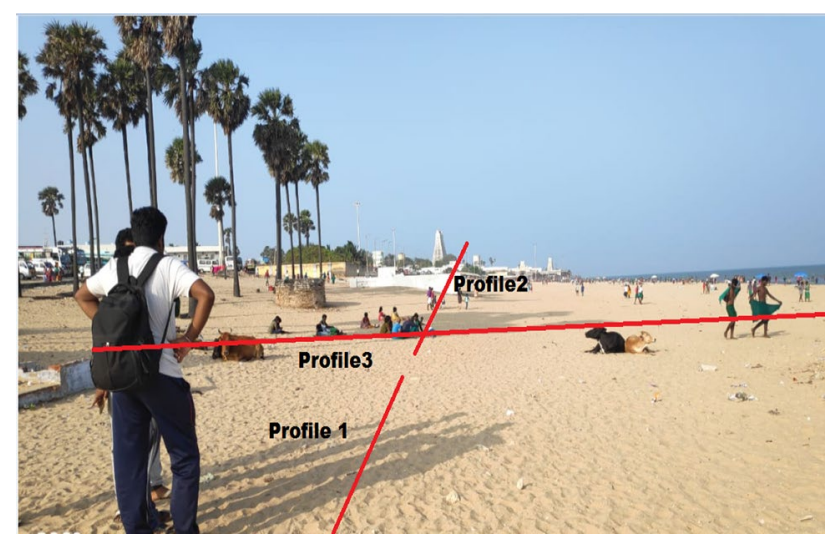

Fig. 12 Tiruchendur coastal shoreline area

deGroot-Hedlin (1990), Jones and Alan (1988), Duque and Carlos (2008), Falgàs (2009), Demirci and İsmail (2017), Albouy et al. (2001). The magnetotelluric method has been used by ADMT-300S, equipment with the help of M, N copper probe continuously shifted by equal distance and depth of coverage which was also changed to cover $300 \mathrm{~m}$. The resistivity variation clearly democrats the different soil, rock types and coastal boundaries. The fresh/saline water interface was also distinguished with the help of magnetotelluric images.

The magnetotelluric method is useful for subsurface deep or aquifer study. The aquifer thickness, freshwater movement, saline intrusion, folded and faulted tectonic movement of landscapes Geomorphologic changes of the river and coastal sediment into meta-sedimentary rock were studied.

The petrological study of the soil type and rock type in the area showed that it was mostly covered by the shell, sandstone, calcareous sandstone, sandy loam, clay loam, shell with lime material, calcareous limestone and paleomarine clay deposits in the study area.

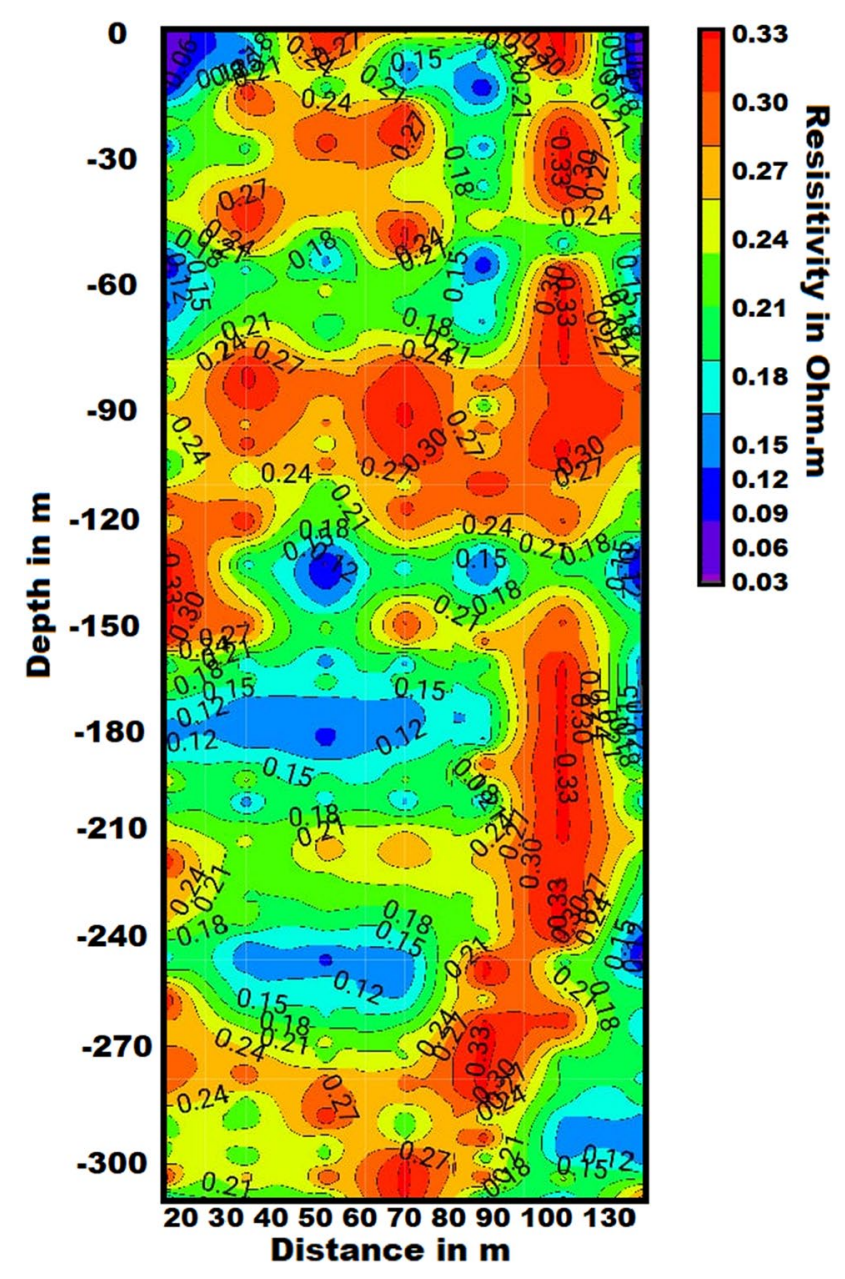

Fig. 13 Magnetotelluric method profile 1 at Tiruchendur coast

\section{Tiruchendur profile 1}

Profile 1 is at a distance of $130 \mathrm{~m}$ parallel to the coast of Tiruchendur terrace. The other side of terrace has highly intrusive rock from deeper level range of $0.27-0.33 \Omega$.m. 


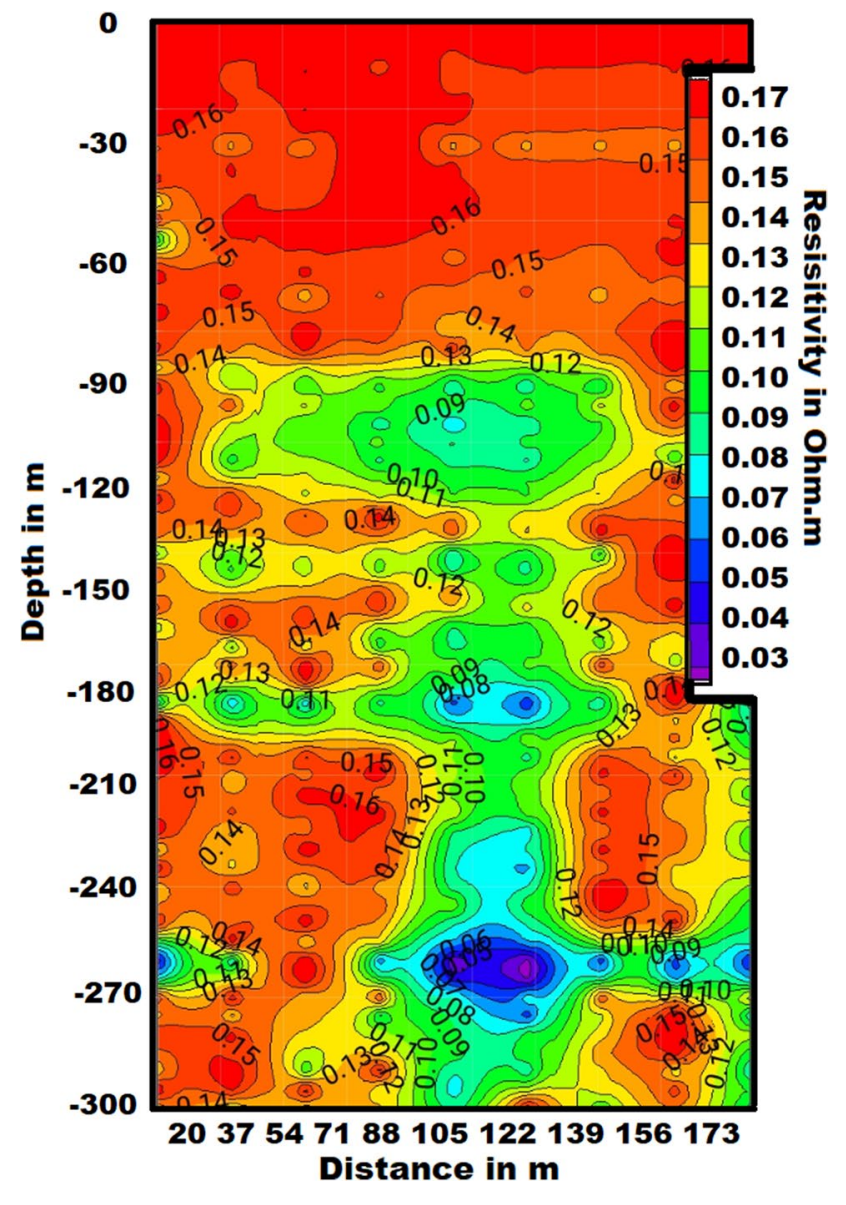

Fig. 14 Magnetotelluric method profile 2 at Tiruchendur coast

The temple of Murugan is placed on the hard terrace. The lowest value of $0.03-0.06 \Omega . \mathrm{m}$ is indicating the SGD flow. The SGD discharge is at the depth of $30 \mathrm{~m}, 60 \mathrm{~m}, 80 \mathrm{~m}$ and $120 \mathrm{~m}$ depth in the magnetotelluric method. (Fig. 13).

\section{Tiruchendur profile 2}

Tiruchendur profile 2 covers a stretch of east to west a distance of $170 \mathrm{~m}$ the range of resistivity $0.03-0.07$ and this indicates the high seawater intrusion in the highly weathered granitic, gneissic rock. The range of resistivity 0.14 to 0.317 ohms is also indicating the highly lithified meta-sedimentary rock associated with Charnockite. The freshwater SGD is occurring at the depth of $60 \mathrm{~m}$ at a resistivity of $0.03-0.04$ $\Omega$. (Fig. 14).

\section{Tiruchendur profile 3}

Profile 3 is measured in Tiruchendur coast E-W direction for a distance of $173 \mathrm{~m}$. The highrock has neem completely sheared by oceanic and continental plate movements and the coastal terrace layer was scanned in magnetotelluric method.

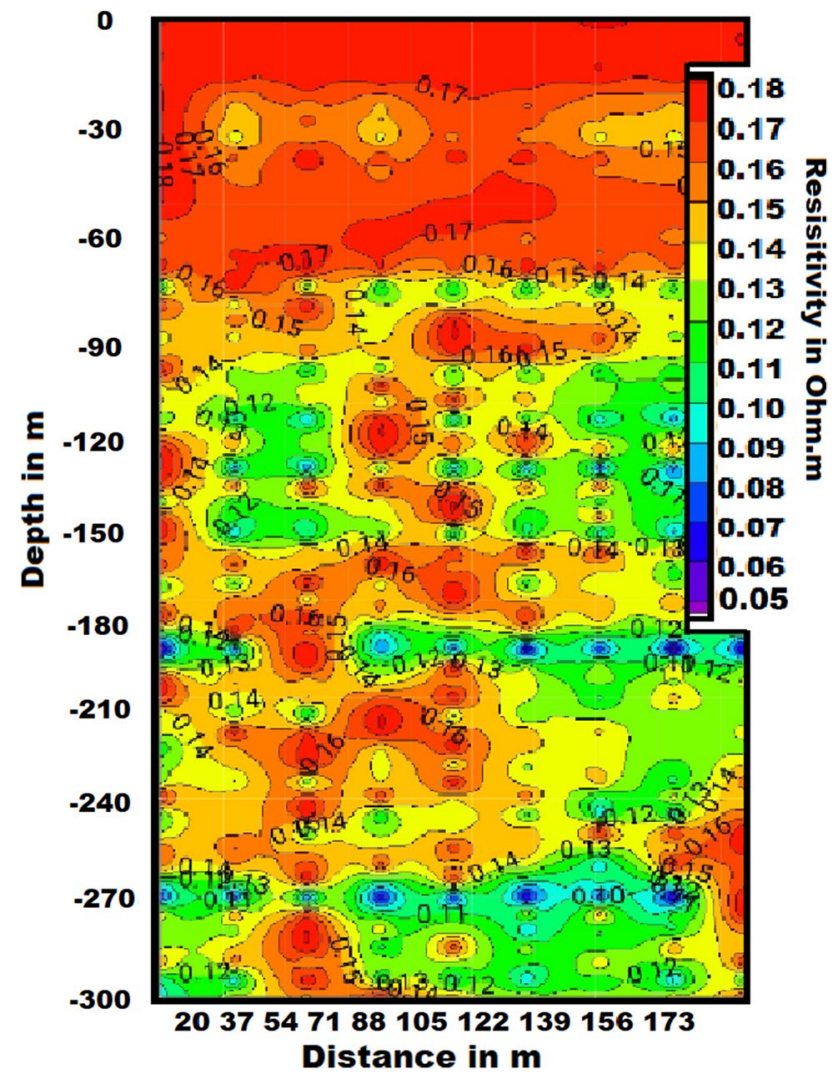

Fig. 15 Magnetotelluric method profile 3 at Tiruchendur coast

Table 1 Magnetotelluric Profile in Tiruchendur Terrace and SGD flow rate Estimation using Darcy's law

\begin{tabular}{lllll}
\hline Locations & SGD depth(m) & dh/dl & $\begin{array}{l}\text { Hydraulic Con- } \\
\text { ductivity of the } \\
\text { rock }\end{array}$ & Q (m/day) \\
\hline Profile1 & 3 & 0.083333 & $1 \times 10^{-3.6}$ & 0.622 \\
& 5 & 0.166667 & $1 \times 10^{-6}$ & 0.1727 \\
Profile2 & 10 & 0.166667 & $1 \times 10^{-3.6}$ & 0.0691 \\
& 20 & 0.333333 & $1 \times 10^{-8}$ & 0.2073 \\
Profile 3 & 10 & 0.5 & $1 \times 10^{-3.6}$ & 0.0518 \\
\hline
\end{tabular}

The hard and compact rock of gneissic, Charnockite is massively formed in $30 \mathrm{~m}, 60 \mathrm{~m}$, and $90 \mathrm{~m}$ depth and freshwater is discharged in the same depth. (Fig. 15).

The Darcy's flow rate calculation formula was used to estimate the SGD flow rate. Ravindran and Ramanujam (2014).

In the Darcy's law, is $\mathrm{Q}=\mathrm{ki}$; Where, $\mathrm{Q}$ : Flow rate, $\mathrm{m} / \mathrm{s}$; $\mathrm{k}$ : Hydraulic conductivity, in $\mathrm{m} / \mathrm{s}$; I: Hydraulic gradient, dimensionless; A: Flow cross section area, in $\mathrm{m}^{2}$.

$\mathbf{Q}=\mathbf{k i A}$ 
Fig. 16 Continental and Oceaic plate margin and coastal ridge formation

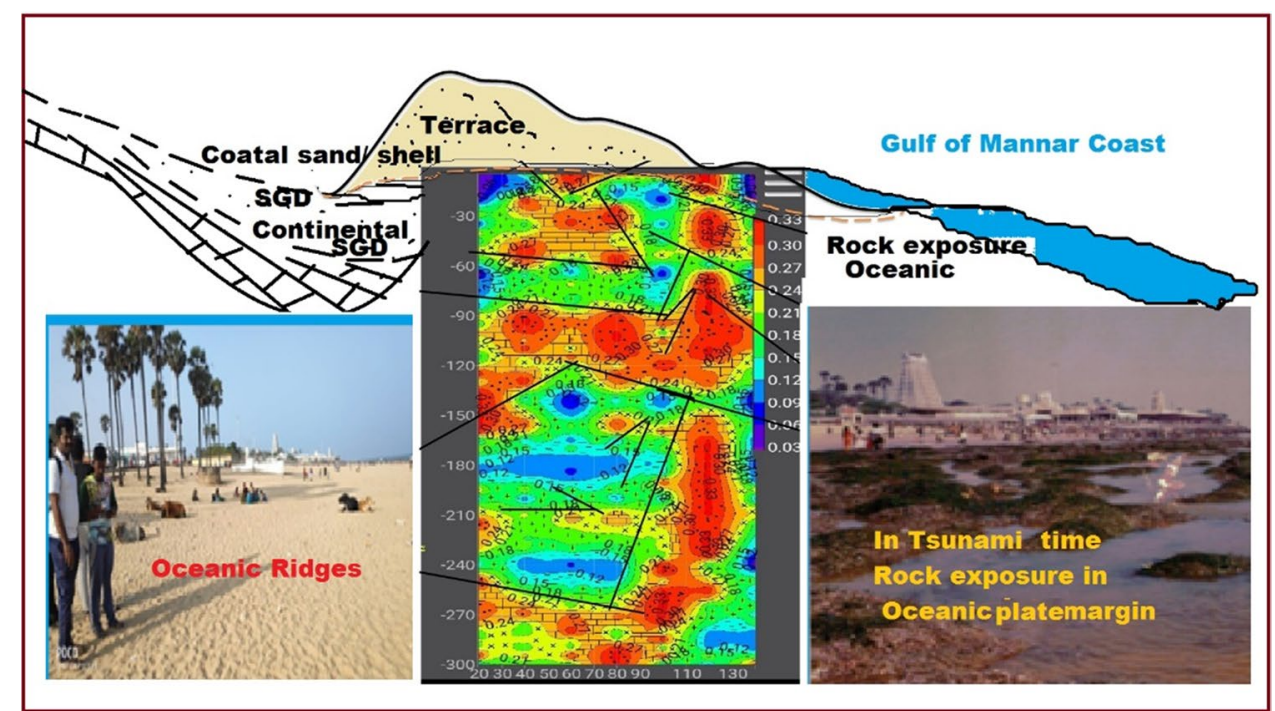

Fig. 17 Magnetotelluric method profile 1, 2 parallel coast compile map Coastal aquifer and coastal terrace map at Tiruchendur coast

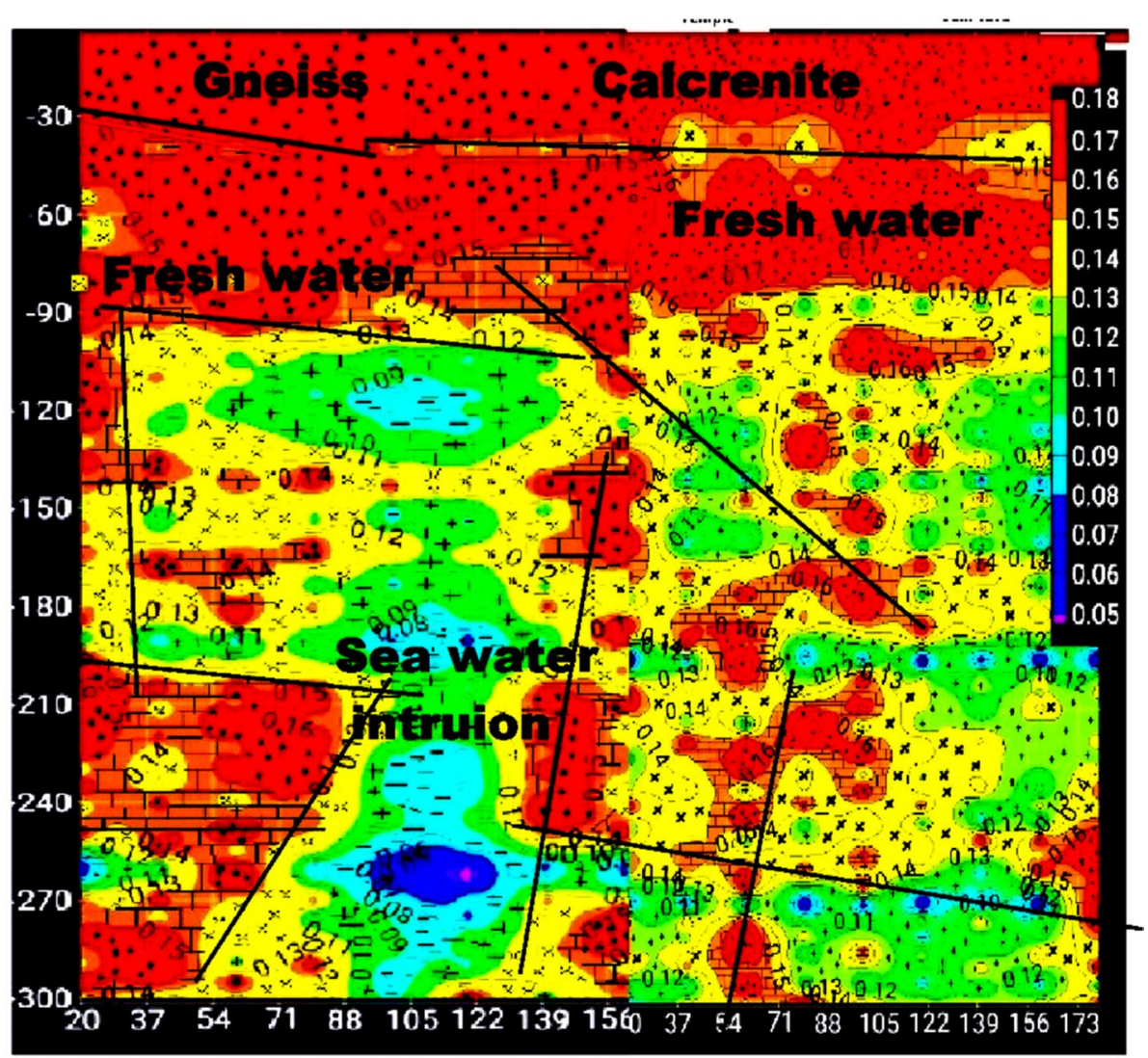

\section{BW data collection for rock/soil identification}

In the study area in two places near Tiruchendur, beach sampling was collected by depth-wise change of subsurface soil, lithology study. The geotechnical study was done with the help of hand auguring and hammering techniques, the collected samples were analyzed using sieve techniques, and the soil properties for the construction in near coastal area were studied.

Profile 1 geotechnical study of soil variation shows fine sand, silty-clay, sandy loam, coarse sand with water table depth is used to correlate the resistivity data. Profile 1 is well graded and silty mixture with silty -clay-sandy mixture up to $6 \mathrm{ft}$ is expensive clay rich area. Profile 2 was near the coastal 

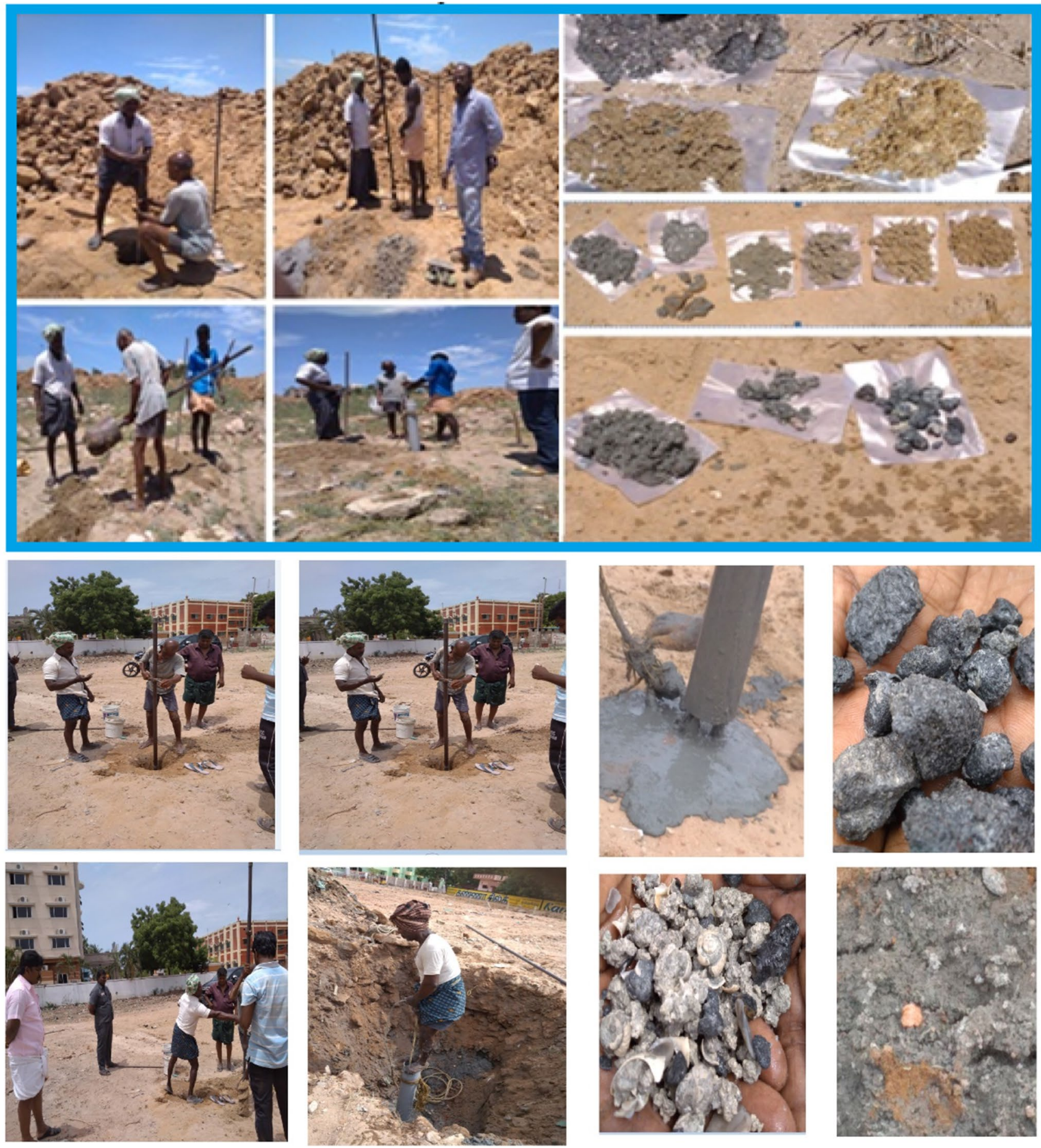

Fig. 18 Depth-wise soil of Soil sandy-silt-clay soil, well sorted sediments, shell material and gneissic rock

and estuarine area and the well logging estuarine site was high well and had fine graded sand, coarse sand with water column at depth of $9 \mathrm{ft}$ around $3.3 \mathrm{~m}$ depth. The clay with shell material at depth of $15 \mathrm{ft}$ occurs in this area due to river, wave and tidal depositional environment.
This systematic sieve method has adopted for twenty-four soil samples and they were collected from in and around Tiruchendur coast. The grain size study using mechanical sieving method with systematic analysis using sieve involves a column of sieve wire mesh cloth and a different sieve size. 


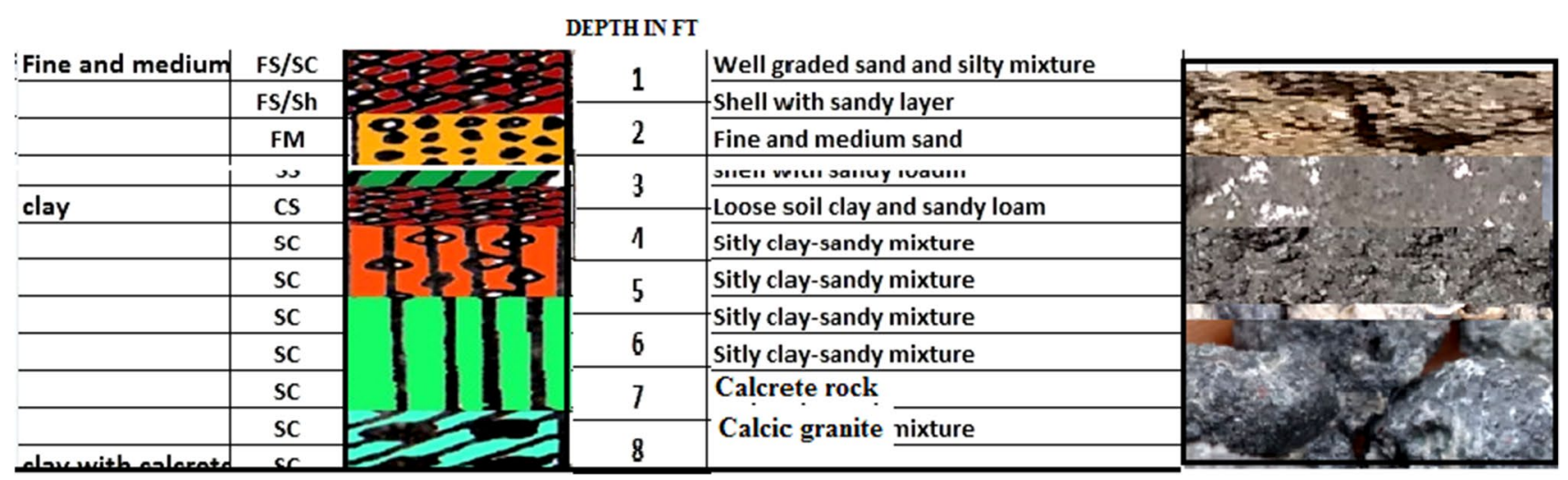

Fig. 19 Depth-wise soil classifications

The size-wise grain separately settled in the upper to lower opening sieve size. The sieve shaker is equipment used for the experimental test. The collected sample was analyzed mechanically by sieving method using sieve shaker for the size and shape of soil grains (Fig. 20).

The geotechnical grain size textural characteristic study supported the identification of sorting geomorphology, marine, ocean, and estuarine, and the earlier studies have been agreed by Friedman (1961a, b, 1978), Nitsche a et al. (2007), Chen et al. (2013), Komar et al. (1984), Guillen and Palanques (1996). The statistical grain size distribution of statistical analysis grandistat has studied in previous work done by Blott and Pye (2001), Makaske and Augustinus (1998). Flemming (2007) An Indian estuarine and associated geomorphologic study was carried out by Venkatramanan, S, et al. 2011; the coastal geomorphology of dune and associated textural study had done by Friedman (1961). Folk and Ward (1957), Watson (2013), Punzo et al. (2017), Venkatraman et al. (2011).

The graphical representation of the Kurtosis value is plotted in the lower side of graph which indicated the mesokurtic, platykurtic, and melanokurtic sizes. The mean value of the grains min 1.8 and max 2.2 is obtained from the graph. The sorting of grains is $0.164-0.0781$ and kurtosis $0.517-1.373$. The fine sand formation occurred in the sampling point of $1,2,6,7$, and medium sand is found in the samples of 3, 4, 9, 10 .

Sieve analysis of terrace sediments was analyzed with the mechanical sieve analysis of grains. The excel worksheet plotted in the percentage-wise and used to explain the size in the terrace area.

The statistical analysis mean, median, mode, skewness, kurtosis values obtained from the sieve analysis. The sorting of the grain is used to identify the depositional environment of shallow marine, beach, and environments. The lagoon stagnant water altered to hypersaline water and becomes shallow marine deposition.

\section{Water geochemistry}

The geochemical study of water samples in NaaliKinaru and the adjoining area of Tiruchendur terrace was used to identify the SGD in the terrace. The cation and anion concentration study of water samples from open well, bore well and push point was done with the help of water sampling from the beach shoreline side (Srinivas et al. 2020). The systematic water sample collection was followed in the study. The water bottle is completely sealed and monitored the cation and anion in the collected water samples. The major ion and cation concentrations were analyzed in the laboratory of V.O. Chidambaram College, Thoothukudi.

The hydrochemical facies of $\mathrm{Ca}^{2+}, \mathrm{Mg}^{2+}, \mathrm{Na}^{+}, \mathrm{K}^{+}$, $\mathrm{HCO}_{3}{ }^{-}, \mathrm{So}^{2-}{ }_{4}, \mathrm{Cl}^{-}, \mathrm{No}_{3}{ }^{-}$values range for maximum and minimum $21-136 ; 13-42$ and $11-36$; 27-75; 132-156.

\section{Result and discussion}

The study area is tectonically associated with the Achaean-tertiary contact in the trends of NNE-SSW linear fault of Tamirabarani River. The microscopic and megascopic showed rock and minerals such as calcarenite, Kankar, shell limestone, clay, sandy soil, sandy clay, sandy loom, sandstone, calcareous limestone, gneissic rock and the Charnockite basement was formed in the folded nature (Figs. 1, $2,3,4)$. The Azimuthal square array method is a supporting tool for indirect identification the depth of soil, rock type, seawater, freshwater (10 $\Omega . \mathrm{m}, 10 \mathrm{~m}$ depth) in shallow perched aquifer and (4 $\Omega . \mathrm{m}$ in $70 \mathrm{~m}$ depth) (Figs. 5, 6,7,8,9). The 2D ERI profiles $1 \mathrm{SGD}$ was recognize at $10 \mathrm{~m}$ resistivity of $4-5 \Omega . \mathrm{m}$, in profile 2 is 4 ohms at depth of $13 \mathrm{~m}$ (Figs. 10, $11,12)$.

In the magneto telluric profile1 SGD is found in the depth of $30,60,80,120 \mathrm{~m}$ and resistivity was $0.03-0.06 \Omega . \mathrm{m}$. The profile 2 SGD flow is located at a depth $10,30 \mathrm{~m}$ of 

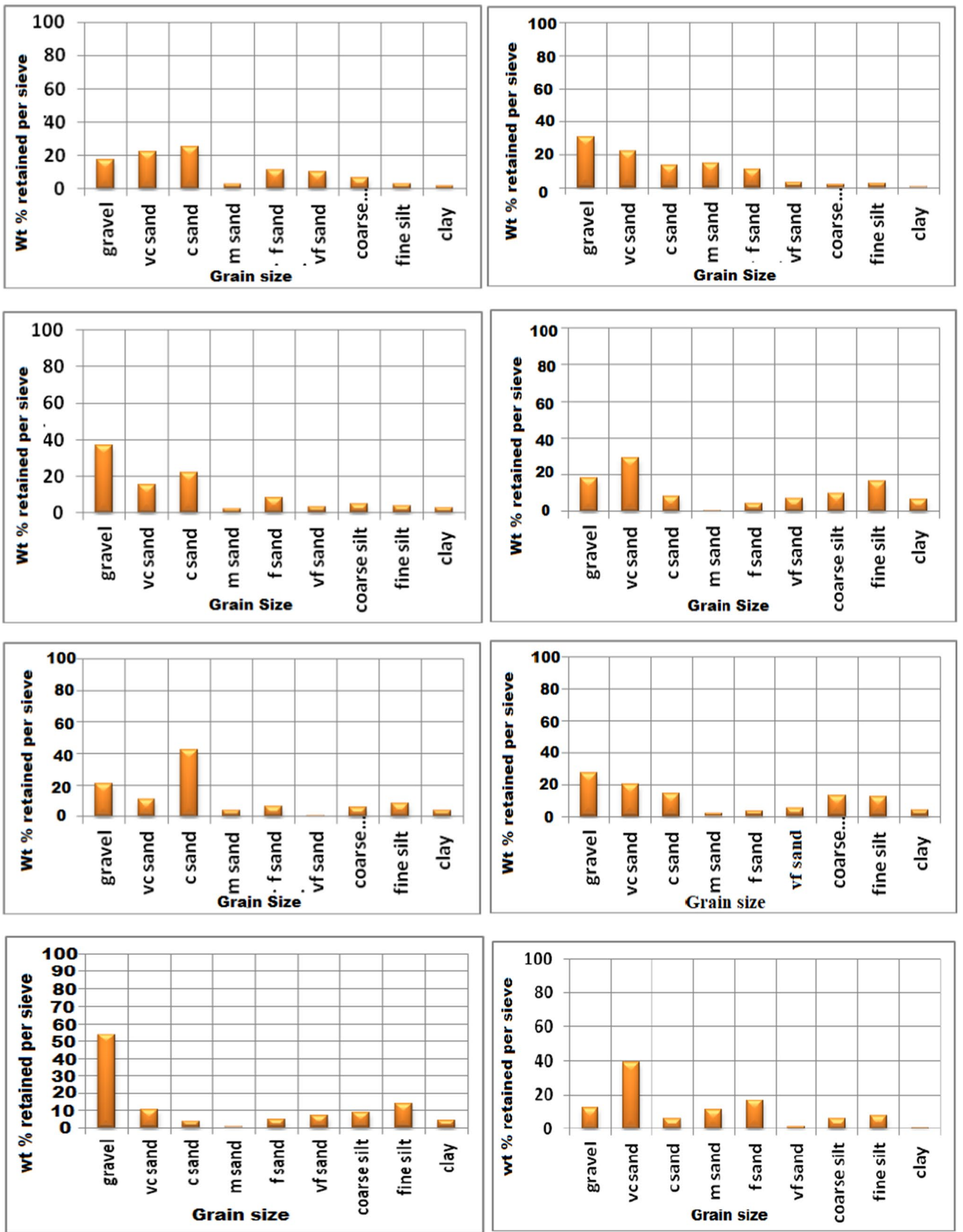

Fig. 20 Cummulative frequency curve for phi values (vs.) grain size from samples 
Table 2 Grain size analysis and statistical analysis

\begin{tabular}{lllllllll}
\hline Stations & Mean & Sorting & Skewness & Kurtosis & Mean & Sorting & Skewness & Kurtosis \\
\hline 1 & 2.112 & 0.569 & 0.205 & 0.806 & Fine Sand & Moderately Well Sorted & Fine Skewed & Platykurtic \\
2 & 2.269 & 0.678 & 0.164 & 0.537 & Fine Sand & Moderately Well Sorted & Fine Skewed & Very Platykurtic \\
3 & 1.981 & 0.543 & 0.355 & 0.833 & Medium Sand & Moderately Well Sorted & Very Fine Skewed & Platykurtic \\
4 & 1.794 & 0.450 & 0.335 & 0.846 & Medium Sand & Well Sorted & Very Fine Skewed & Platykurtic \\
5 & 1.831 & 0.554 & 0.443 & 1.133 & Medium Sand & Moderately Well Sorted & Very Fine Skewed & Leptokurtic \\
6 & 2.130 & 0.712 & 0.517 & 0.584 & Fine Sand & Moderately Sorted & Very Fine Skewed & Very Platykurtic \\
7 & 2.029 & 0.626 & 0.394 & 1.373 & Fine Sand & Moderately Well Sorted & Very Fine Skewed & Leptokurtic \\
8 & 2.062 & 0.695 & 0.480 & 0.590 & Medium Sand & Moderately Well Sorted & Very Fine Skewed & Very Platykurtic \\
9 & 1.940 & 0.721 & 0.781 & 0.584 & Medium Sand & Moderately Sorted & Very Fine Skewed & Very Platykurtic \\
10 & 1.906 & 0.504 & 0.555 & 0.942 & Medium Sand & Moderately Well Sorted & Very Fine Skewed & Mesokurtic \\
\hline
\end{tabular}

Table 3 Hydrochemical facies evolution diagram

\begin{tabular}{|c|c|c|c|c|c|c|c|c|c|c|}
\hline Wells & $\mathrm{Ca}^{2+}$ & $\mathrm{Mg}^{2+}$ & $\mathrm{Na}^{+}$ & $\mathrm{K}^{+}$ & $\mathrm{HCO}_{3}^{-}$ & $\mathrm{SO}_{4}{ }^{2-}$ & $\mathrm{Cl}^{-}$ & $\mathrm{NO}_{3}^{-}$ & Phase & Facies \\
\hline $\mathrm{T} 1$ & 21 & 29 & 17 & 19 & 660 & 132 & 159 & 0.001 & Fresh & $\mathrm{Mg}-\mathrm{HCO}_{3}$ \\
\hline $\mathrm{T} 2$ & 77 & 128 & 36 & 22 & 758 & 143 & 66 & 0.001 & Fresh & $\mathrm{Mg}-\mathrm{HCO}_{3}$ \\
\hline $\mathrm{T} 3$ & 29 & 31 & 18 & 11 & 457 & 122 & 81 & 0.002 & Fresh & $\mathrm{Mg}-\mathrm{HCO}_{3}$ \\
\hline $\mathrm{T} 4$ & 143 & 27 & 19 & 13 & 571 & 223 & 138 & 0.002 & Intrus & $\mathrm{Ca}-\mathrm{HCO}_{3}$ \\
\hline $\mathrm{T} 5$ & 57 & 55 & 42 & 36 & 464 & 439 & 196 & 0.001 & Fresh & $\mathrm{MixMg}-\mathrm{MixSO}_{4}$ \\
\hline T6 & 101 & 25 & 21 & 11 & 305 & 342 & 128 & 0.002 & Intrus & $\mathrm{Ca}-\mathrm{MixSO}_{4}$ \\
\hline $\mathrm{T} 7$ & 56 & 112 & 36 & 26 & 417 & 519 & 112 & 0.003 & Intrus & $\mathrm{Mg}-\mathrm{SO}_{4}$ \\
\hline $\mathrm{T} 8$ & 22 & 45 & 34 & 15 & 596 & 288 & 88 & 0.001 & Fresh & $\mathrm{Mg}-\mathrm{HCO}_{3}$ \\
\hline T9 & 37 & 153 & 13 & 23 & 275 & 567 & 162 & 0.001 & Intrus & $\mathrm{Mg}-\mathrm{SO}_{4}$ \\
\hline $\mathrm{T} 10$ & 136 & 32 & 55 & 12 & 705 & 278 & 53.4 & 0.002 & Fresh & $\mathrm{Ca}-\mathrm{HCO}_{3}$ \\
\hline
\end{tabular}

Fig. 21 Hydrochemical facies evolution diagram of Tiruchendur coast

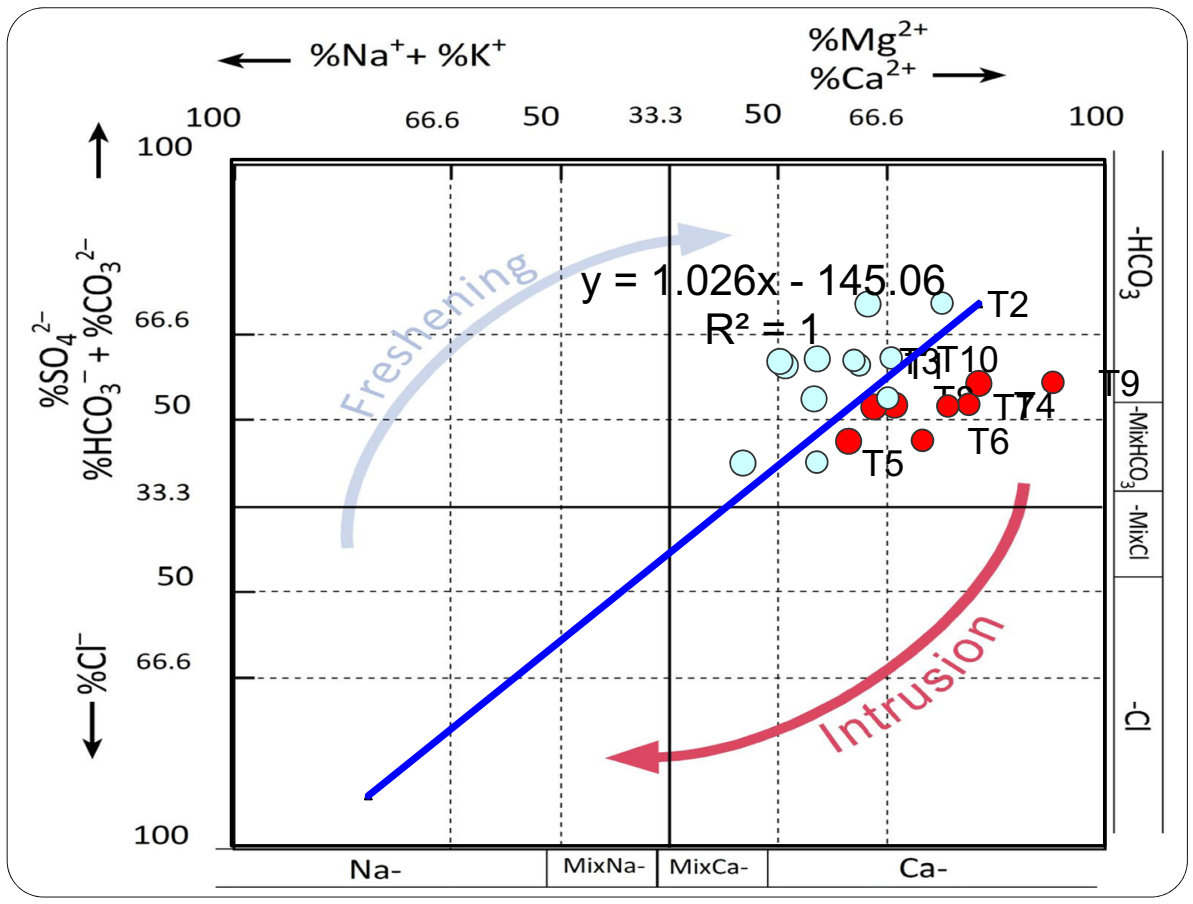


resistivity 0.03-0.04 $\Omega$.m. In Profile 3, freshwater resistivity is ranging from $0.05-0.06 \Omega . \mathrm{m}$ at depth of $30,60,90 \mathrm{~m}$ (Fig. 13, 14, 15).

The SGD flux of the flow rate $\mathrm{Q}$ is measured using the Darcy's law of two different flows in the aquifer formation of water through the hydraulic gradient with rock types or hydraulic conductivity of formation. Profile 1 in shallow aquifer water system was $0.6220 \mathrm{~m} 3 /$ day; it was 0.17279 $\mathrm{m} 3 /$ day in Profile 2 is having $0.057 \mathrm{~m} 3 /$ day and profile 3 is $0.1156 \mathrm{~m} 3 /$ day (Table 1) (Figs. 16, 17 18).

The grain size analysis is used to find out the fine sand, medium sand in dune, beach, and estuarine environment in and around the terrace area (Figs. 19 and 20) Table 2.

The groundwater quality and geochemical facies was studied using the scientific method freshwater $(\mathrm{Na}, \mathrm{Mg}$ surface), seawater ( $\mathrm{Na}, \mathrm{Mg}$ defects). The proper systematic geochemical analysis showed the cation and anion value of water at the minimum and maximum value of $\mathrm{Ca}, \mathrm{Mg}, \mathrm{Na}$, $\mathrm{K}, \mathrm{Hco}_{3}, \mathrm{SO} 4, \mathrm{No}_{3}$, and freshwater phase of $1,2,3,5,8,10$ and saline/seawater zone $4,6,7,9$, intrusion of seawater (Table 3). The hydrochemical plot of diagram of samples is T1, T2, T3, T5, T8 and T10 which are plotted to the freshwater zone. Then, remaining samples $\mathrm{T} 4, \mathrm{~T} 6, \mathrm{~T} 7$, and $\mathrm{T} 9$ plot of seawater intrusion zone. The facies of $\mathrm{Mg}^{2+}, \mathrm{HCO}_{3}{ }^{-}$is a freshwater zone (Fig. 21). The $\mathrm{Ca}^{2+}, \mathrm{HCO}_{3}^{-}$seawater intrusion zone of the study area. The shallow aquifer well acts as a permeable layer of perched aquifer lens of water table available in "Nallikinaru." The open small freshwater well is utilized for Murugan Temple pleasing water for 25,000 people visiting every day this temple. The bore well soil and rock sampling was used to validate the azimuthal square array, magnetotelluric and 2D ERI data identified the soil and rock of the study area. The geophysical and geochemical assessment to find out the Calcarinite rock which act as leaky aquifer from Avudaiyur Kulam (Western side of the Terrace) in to Sea shore area. It is a useful study for SGD flux rate for public using up of groundwater in coastal aquifer system.

\section{Conclusion}

The study has analyzed the submarine groundwater discharge flows that take place in Tiruchendur by subsurface water penetration into the sea. It is used to investigate the type of rock, the quality and quantity of soil and groundwater. This study focuses on SGD in porous sandstone with water permeability for public utility. Since the density of freshwater is much lower than that of seawater, freshwater floats to the surface in coastal areas. The floating of freshwater (SGD in the form of perched aquifer) oozed out to occur in the seaside area of the Murugan Temple in Tiruchendur. The cliffs and rocky coasts are formed due to uplift, and freshwater springs can be seen under the sea. The porous sandstone and sand bar are of sandy nature with dunes area occurring in Tiruchendur beach. SGD study has been conducted using electrical resistivity and geochemical groundwater parameters, as well as particle size analysis of water behavior in the soil and rocks; resistivity studies were based on the information from VES profiles, 2D profiles and magnetotelluric profiles of SGD under the sea is at a level of 10 feet 30 feet 60 feet 90 feet. Samples of groundwater in dug, open, bore wells were collected from the study area, for water quality and quantity of SGD water for public utility. Groundwater quality and geochemical phases were adopted as scientific methods for analyzing freshwater $(\mathrm{Na}$, $\mathrm{Mg}$ surface) and seawater ( $\mathrm{Na}, \mathrm{Mg}$ defects). The minimum and maximum values of $\mathrm{Ca}, \mathrm{Mg}, \mathrm{Na}, \mathrm{K}, \mathrm{HCO}_{3}, \mathrm{SO}_{4}, \mathrm{NO}_{3}$ were seen on fresh water phase $1,2,3,5,8,10$ and where salt water/sea water 4 , Areas 6,7, and 9 where the sea water invades. The water chemistry diagram of the chart plotted the samples T1, T2, T3, T5, T8, and T10 into the freshwater area. Then, the remaining samples T4, T6, T7 and T9 showed seawater intrusion in the area map. The SGD in the coastal environment of water is mixed with fresh, saline and seawater. The significant variation of water geochemistry and electrical resistivity has been the method used to find out SGD flow in porous sandstone in Tiruchendur area.

Acknowledgements First author expresses his sincere thanks to $\mathrm{Mr}$. A.P.C.V. Chockalingam, Secretary, Dr.C. Veerabahu, Principal,, V.O.C. College, Thoothukuidi. The help extended by Dr. P. Sivasubramanian, Professor and Head, Department of Geology, V.O.Chidambaram College, Thoothookudi is also acknowledged. I would like to thank to S.K. Bansal, Director, Ministry of Earth Scince, New Delhi. Director, NCESS, Triuvananthapuram and Dr. Suresh Babu, SGD - National Network Project Co-ordinator who sanctioned project Ref No. NCESS/ MOES/ 402/ GIA/2019 dt:29.03.2019.

Funding The author(s) received no specific funding for this work.

Data availability Open Access This article is distributed under the terms of the Creative Commons Attribution 4.0 International License (http://creativecommons.org/licenses/by/4.0/), which permits unrestricted use, distribution, and reproduction in any medium, provided you give appropriate credit to the original author(s) and the source, provide a link to the Creative Commons license, and indicate if changes were made.

\section{Compliance with ethical standards}

Conflict of interest No conflict of interest is confirmed.

Open Access This article is licensed under a Creative Commons Attribution 4.0 International License, which permits use, sharing, adaptation, distribution and reproduction in any medium or format, as long as you give appropriate credit to the original author(s) and the source, provide a link to the Creative Commons licence, and indicate if changes were made. The images or other third party material in this article are included in the article's Creative Commons licence, unless indicated otherwise in a credit line to the material. If material is not included in

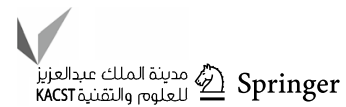


the article's Creative Commons licence and your intended use is not permitted by statutory regulation or exceeds the permitted use, you will need to obtain permission directly from the copyright holder. To view a copy of this licence, visit http://creativecommons.org/licenses/by/4.0/.

\section{References}

Abdelzaher M, Nishijima J, Saibi H, El-Qady G, Massoud U, Soliman M, Younis A, Ehara S (2012) A coastal aquifer study using magnetotelluric and gravity methods in Abo Zenema, Egypt. Pure Appl Geophys 169(9):1679-1692. https://doi.org/10.1007/ s00024-011-0407-y

Albouy Y, Andrieux P, Rakotondrasoa G, Ritz M, Descloitres M, Join J-L, Rasolomanana E (2001) Mapping coastal aquifers by joint inversion of DC and TEM soundings-three case histories. Groundwater 39(1):87-97. https://doi.org/10.1111/j.1745-6584. 2001.tb00354.x

Antony Ravindran A (2012) Azimuthal square array resistivity method and goundwater exploration in Sanganoor, Coimbatore District, Tamilnadu, India. Res J Recent Sci ISSN 2277:2502

Babu DS, Anish M, Vivekanandan KL, Ramanujam N, Murugan KN, Ravindran AA (2009b) An account of submarine groundwater discharge from the SW Indian coastal zone. J Coast Res 25(1):91104. https://doi.org/10.2112/07-0881.1

Babu DS, Khandekar A, Bhagat C, Singh A, Jain V, Verma M, Kumar M (2021) Evaluation, effect and utilization of submarine groundwater discharge for coastal population and ecosystem: a special emphasis on indian coastline. J Environ Manage 277:111362. https://doi.org/10.1016/j.jenvman.2020.111362

Barnard PL, Foxgrover AC, Elias EP, Erikson LH, Hein JR, McGann M, Woodrow DL (2013) Integration of bed characteristics, geochemical tracers, current measurements, and numerical modeling for assessing the provenance of beach sand in the San Francisco Bay Coastal System. Marine Geol 336:120-145. https://doi.org/ 10.1016/j.margeo.2012.11.008

Blott SJ, Pye K (2001) Gradistat: a grain size distribution and statistic package for the analysis of unconsolidated sediments. Earth Surf Process Landforms 26:1337-1348. https://doi.org/10.1002/esp. 261

Burnett WC, Aggarwal PK, Aureli A, Bokuniewicz H, Cable JE, Charette MA, Kontar E et al (2006) Quantifying submarine groundwater discharge in the coastal zone via multiple methods. Sci Total Environ 367(2-3):498-543. https://doi.org/10.1016/j. scitotenv.2006.05.009

Chen G, Yi L, Chen S, Huang H, Liu Y, Yonghang X, Cao J (2013) Partitioning of grain-size components of estuarine sediments and implications for sediment transport in southwestern Laizhou Bay, China. Chin J Oceanol Limnol 31(4):895-906. https://doi.org/10. 1007/s00343-013-2304-y

deGroot-Hedlin C, Constable S (1990) Occam's inversion to generate smooth, two-dimensional models from magnetotelluric data. Geophysics 55(12):1613-1624. https://doi.org/10.1190/1.1442813

Demirci İ, EminCandansayar M, Vafidis A, Soupios P (2017) Two dimensional joint inversion of direct current resistivity, radiomagnetotelluric and seismic refraction data: an application from Bafra Plain, Turkey. J Appl Geophys 139:316-330. https://doi. org/10.1016/j.jappgeo.2017.03.002

Duque C, Calvache ML, Pedrera A, Martín-Rosales W, López-Chicano M (2008) Combined time domain electromagnetic soundings and gravimetry to determine marine intrusion in a detrital coastal aquifer (Southern Spain). J Hydrol 349(3-4):536-547. https://doi.org/ 10.1016/j.jhydrol.2007.11.031

Duque C, Russoniello CJ, Rosenberry DO (2020) History and evolution of seepage meters for quantifying flow between groundwater and surface water: part 2-Marine settings and submarine groundwater discharge. Earth Sci Rev 204:103168. https://doi.org/10.1016/j. earscirev.2020.103168

Falgàs E, Ledo J, Marcuello A, Queralt P (2009) Monitoring freshwater-seawater interface dynamics with audiomagnetotelluric data. Near Surf Geophys. https://doi.org/10.3997/1873-0604.2009038

Fiore D, Vincenzo MP, Cavuoto G, Galli P, Mazzola S, Pelosi N, Tarallo D (2020) Geophysical approach to study the potential ocean wave-induced liquefaction: an example at Magoodhoo Island (Faafu Atoll, Maldives, Indian Ocean). Mar Geophys Res 41(2):1-19. https://doi.org/10.1007/s11001-020-09408-8

Flemming BW (2007) The influence of grain-size analysis methods and sediment mixing on curve shapes and textural parameters: implications for sediment trend analysis. Sediment Geol 202:425-435. https://doi.org/10.1016/j.sedgeo.2007.03.018

Folk RL, Ward WC (1957) Brazos River bar: a study in the significance of grain size parameters. J Sediment Petrol 27:3-26. https://doi. org/10.1306/74D70646-2B21-11D7-8648000102C1865D

Friedman GM (1961a) Distinction between dune, beach and river sands from textural characteristics. J Sed Petrol 31:514-529. https://doi. org/10.1306/74D70BCD-2B21-11D7-8648000102C1865D

Friedman GM (1961b) On sorting, sorting coefficients and the log normality of the grain- size distributions ofsandstones. J Geol 70:737-753. https://doi.org/10.1086/jg.70.6.30066373

Friedman, G. M., \& Sanders, J. E. (1978). Principles of sedimentology. New York: John Wiley Sons, p. 792. ISBN 0471752452.

George ME, Babu DS, Akhil T, Rafeeque MK (2018) Investigation on submarine groundwater discharge at Kozhikkode Coastal Aquifer, SW Western Ghats. J Geol Soc India 92(5):626-633. https://doi. org/10.1007/s 12594-018-1077-5

Guillen J, Palanques A (1996) Short and medium term grain size changes in deltaic beaches (Elbro Delta, NW Mediterranean). Sediment Geol 101:55-67. https://doi.org/10.1016/0037-0738(95) 00021-6

Habberjam GM (1972) The effects of anisotropy on square array resistivity measurements. Geophys Prospect 20(2):249-266. https:// doi.org/10.1111/j.1365-2478.1972.tb00631.x

Habberjam GM, Watkins GE (1967) The use of a square configuration in resistivity prospecting. Geophys Prospect 15(3):445-467. https://doi.org/10.1111/j.1365-2478.1967.tb01798.x

Henderson RD, Day-Lewis FD, Abarca E, Harvey CF, Karam HN, Liu L, Lane JW (2010) Marine electrical resistivity imaging of submarine groundwater discharge: sensitivity analysis and application in Waquoit Bay, Massachusetts, USA. Hydrogeol J 18(1):173-185. https://doi.org/10.1007/s10040-009-0498-z

Jeyapaul VK, Jebamalai ARA, Selvam RA, Krishnaveni AS, Johnson AAPA (2020) A case study of freshwater discharge in porous calcarenite formation in coastal terrace at Manapad, South India. Carbon Evaporites 35(4):1-14. https://doi.org/10.1007/ s13146-020-00641-1

Jones AG (1988) Static shift of magneto telluric data and its removal in a sedimentary basin environment. Geophysics 53(7):967-978. https://doi.org/10.1190/1.1442533

Komar PD, Cui B (1984) The analysis of grain-size measurements by sieving and settling-tube techniques. J Sediment Petrol 54:603614. https://doi.org/10.1306/212F8481-2B24-11D7-8648000102 C1865D

Land LA, Paull CK (2000) Submarine karst belt rimming the continental slope in the Straits of Florida. Geo-Mar Lett 20(2):123-132. https://doi.org/10.1007/s003670000041

Li J, Pang Z, Kong Y, Lin F, Wang Y, Wang G, Lv L (2017) An integrated magnetotelluric and gamma exploration of groundwater in fractured granite for small-scale freshwater supply: a case study from the Boshan region, Shandong Province, China. Environ Earth Sci 76(4):163. https://doi.org/10.1007/s12665-017-6486-Z 
Ma Q, Zhang Y (2020) Global research trends and hotspots on submarine groundwater discharge (SGD): a bibliometric analysis. Int J Environ Res Pub Health 17(3):830. https://doi.org/10.3390/ijerp h17030830

Madhavaraju J, Armstrong-Altrin JS, James RA, Hussain SM (2021) Palaeoenvironment and provenance signatures inferred from quartz grain surface features: a case study from Huatabampu and Altata beaches, Gulf of California, Mexico. J South Am Earth Sciences. https://doi.org/10.1016/j.jsames.2021.103441

Makaske B, Augustinus PGEF (1998) Morphologic changes of a micro-tidal, low wave energy beach face during a spring-neap cycle, Rhone-Delta, France. J Coast Res 14:632-645

Manivannan V, Elango L (2019) Seawater intrusion and submarine groundwater discharge along the Indian coast. Environ Sci Pollut Res 26(31):31592-31608. https://doi.org/10.1007/ s11356-019-06103-z

Nitsche FO, Ryan WBF, Carbotte SM, Bell RE, Slagle A, Beriinado C, Flood R, Kenna T, McHugh C (2007) Regional patterns and local variations of sediment distribution in the Hudson River Estuary Estuarine. Coast Shelf Sci 71:259e277. https://doi.org/10.1016/j. ecss.2006.07.021.10.1016/j.ecss.2006.07.021

Peng TR, Chen CTA, Wang CH, Zhang J, Lin YJ (2008) Assessment of terrestrial factors controlling the submarine groundwater discharge in water shortage and highly deformed island of Taiwan, western Pacific Ocean. J Oceanogr 64(2):323-337. https://doi.org/ 10.1007/s10872-008-0026-0

Porubsky WP, Weston NB, Moore WS, Ruppel C, Joye SB (2014) Dynamics of submarine groundwater discharge and associated fluxes of dissolved nutrients, carbon, and trace gases to the coastal zone (Okatee River estuary, South Carolina). Geochim Cosmochim Acta 131:81-97. https://doi.org/10.1016/j.gca.2013.12.030

Prakash R, Srinivasamoorthy K, Gopinath S, Saravanan K (2018) Measurement of submarine groundwater discharge using diverse methods in Coleroon Estuary, Tamil Nadu, India. Appl Water Sci 8(1):1-11. https://doi.org/10.1007/s13201-018-0659-0

Punzo M, Cavuoto G, Tarallo D, Di Fiore V (2017) Ensuring very shallow-water sediment properties: case study from Capo Granitolaharbour, Sicily (Italy). Mar Geophys Res 38(3):313-323. https:// doi.org/10.1007/s11001-017-9313-8

Ravindran AA, Kingston JV, Premshiya KH (2021) Mitigation dredging in seabed geotechnical engineering study using marine 2D ERI and textural characteristics in ThengapattanamHarbour, South India. Geotech Geol Engi 39(2):897-907. https://doi.org/ 10.1007/s10706-020-01530-z

Ravindran AA, Ramanujam N (2014) Detection of submarine groundwater discharge to coastal zone study using $2 \mathrm{~d}$ electrical resistivity imaging study at Manapad, Tuticorin, India. http://hdl.handle.net/ $123456789 / 27258$

Robb JM (1990) Groundwater processes in the submarine environment. Groundw Geomorphol the Role Subsurf Water Earth-Surf Process Landforms 252:267-281

Selvam S, Jesuraja K, Roy PD, Venkatramanan S, Chung SY, Elzain HE, Karthik R (2021a) Assessment of groundwater from an industrial coastal area of south India for human health risk from consumption and irrigation suitability. Environ Res. https://doi. org/10.1016/j.envres.2021.111461

Selvam S, Muthukumar P, Sajeev S, Venkatramanan S, Chung SY, Brindha K, Murugan R (2021b) Quantification of submarine groundwater discharge (SGD) using radon, radium tracers and nutrient inputs in Punnakayal, south coast of India. Geosci Front 12(1):29-38. https://doi.org/10.1016/j.gsf.2020.06.012

Srinivas KNSSS, Kishore PP, Trupti S, Kumar KS, Mysaiah D, Satyanarayana HVS (2020) Delineation of potential groundwater zones using shear wave velocity in Eastern Deccan Volcanic province, India. Pure Appl Geophys 177(12):5861-5879. https:// doi.org/10.1007/s00024-020-02599-6

Suresh Babu DS, Anish M, Vivekanandan KL, Ramanujam N, NathakiriMurugan K, and Antony Ravindran A (2009) An account of submarine groundwater discharge from the SW Indian coastal zone. J Coast Res 91-146

Swarzenski PW, Izbicki JA (2009) Coastal groundwater dynamics off Santa Barbara, California: combining geochemical tracers, electromagnetic seep meters, and electrical resistivity. Estuarine Coast Shelf Sci 83(1):77-89. https://doi.org/10.1016/j.ecss.2009.03.027

Venkatramanan S, Ramkumar T, Anithamari I, Ramesh G (2011) Variation in texture of beach sediments in the vicinity of the Thirumalairajanar river mouth of India. Int J Sediment Res 26:460-470. https://doi.org/10.1016/S1001-6279(12)60005-5

Viso R, McCoy C, Gayes P, Quafisi D (2010) Geological controls on submarine groundwater discharge in Long Bay, South Carolina (USA). Cont Shelf Res 30(3-4):335-341. https://doi.org/10. 1016/j.csr.2009.11.014

Vozoff K (1991) The magnetotelluric method. In: Electromagnetic methods in applied geophysics: Volume 2, Application, Parts A and B. Society of Exploration Geophysicists, pp. 641-712. https:// doi.org/10.1190/1.9781560802686.ch8

Watson EB, Pasternack GB, Gray AB, Goni M, Woolfolk AM (2013) Particle size characterization of historic sediment deposition from a closed estuarine lagoon Central California, Estuarine. Coast Shelf Sci 126:23-33. https://doi.org/10.1016/j.ecss.2013.04.006

Yadav VB, Jha SK, Pulhani V, Tripathi RM (2019) Estimation of submarine groundwater discharge using radium mass-balance in Mumbai Harbour Bay, Mumbai, India. J Radioanal Nucl Chem 319(3):945-952. https://doi.org/10.1007/s10967-018-6373-4

Zhang Y, Santos IR, Li H, Wang Q, Xiao K, Guo H, Wang X (2020) Submarine groundwater discharge drives coastal water quality and nutrient budgets at small and large scales. Geochim Cosmochim Acta 290:201-215. https://doi.org/10.1016/j.gca.2020.08.026

Taniguchi M, Burnett W, Cable JE, Turner JV (2002) Investigation of submarinegroundwater discharge. Hydrol Process 16(11):2115-2129

Publisher's Note Springer Nature remains neutral with regard to jurisdictional claims in published maps and institutional affiliations. 